\title{
Review
}

\section{A Review on the Wear, Corrosion and High-Temperature Resistant Properties of Wire Arc-Sprayed Fe-Based Coatings}

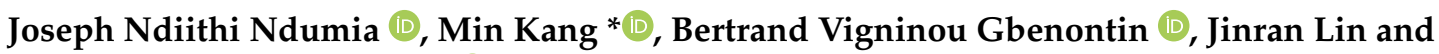 \\ Samuel Mbugua Nyambura \\ College of Engineering, Nanjing Agricultural University, Nanjing 210031, China; \\ 2020212023@stu.njau.edu.cn (J.N.N.); 2019212016@njau.edu.cn (B.V.G.); linjinran@njau.edu.cn (J.L.); \\ accessmbugua@gmail.com (S.M.N.) \\ * Correspondence: kangmin@njau.edu.cn; Tel.: +86-25-58606578
}

check for

updates

Citation: Ndumia, J.N.; Kang, M.; Gbenontin, B.V.; Lin, J.; Nyambura, S.M. A Review on the Wear, Corrosion and High-Temperature Resistant Properties of Wire Arc-Sprayed Fe-Based Coatings. Nanomaterials 2021, 11, 2527. https:// doi.org/10.3390/nano11102527

Academic Editor: Christian Mitterer

Received: 2 August 2021

Accepted: 22 September 2021

Published: 27 September 2021

Publisher's Note: MDPI stays neutral with regard to jurisdictional claims in published maps and institutional affiliations.

Copyright: (c) 2021 by the authors. Licensee MDPI, Basel, Switzerland. This article is an open access article distributed under the terms and conditions of the Creative Commons Attribution (CC BY) license (https:// creativecommons.org/licenses/by/ $4.0 /)$.

\begin{abstract}
Among different thermal spraying methods, arc-spraying has been widely used due to its low operating costs and high deposition efficiency. The rapid progress of cored wire technology in arc-spraying has increased possibilities for the preparation of new Fe-based coating materials with enhanced properties by adding reinforcement particles and alloying elements to suit the different applications. Fe-based coatings have been extensively used because of their high strength, toughness, lower production costs, and availability of raw materials. This makes them suitable replacements for Ni-based coatings in ambient and high-temperature applications. This review discusses the research status and developments of the arc-sprayed Fe-based coatings. The study specifically reviews the wear behavior, corrosion analysis, and high-temperature resistant properties of arc-sprayed Febased coatings, aiming to develop an understanding of the protection mechanisms for Fe-based coatings. The performance of the Fe-based coatings depends on the integrity of the coating structure. Optimizing arc-spraying parameters minimizes defects (pores, grain boundaries, unmelted particles, oxides, and microcracks) that deteriorate the coating properties. High amorphous phase content, ceramic reinforcement particles and alloying elements enhance the corrosion, tribological, and hightemperature resistant properties of Fe-based coatings. In high-temperature applications, Fe-based coatings form oxide scales that protect the coating from further oxidation; thus, it is important to select the optimum composition for the alloying elements.
\end{abstract}

Keywords: wire arc-spraying; Fe-based coatings; corrosion; wear; high-temperature resistance

\section{Introduction}

In recent years, thermal spraying-as a surface modification process-produces films and coatings that improve the properties of metal surfaces. Rapid, sustainable economic growth in different countries has provided an opportunity for growth in the thermal spray industry in all aspects, such as the production of feedstock material, spraying systems, and spraying coating contracts [1]. Among different thermal spraying techniques, wire arc-spraying, also referred to as arc-spraying (AS), finds wide applications in the repair and remanufacturing of structural parts in equipment machinery, mining, and power industries [2-5]. Compared with other thermal spraying methods such as high-velocity oxygen fuel (HVOF) and atmospheric plasma spraying (APS), arc-spraying is preferred due to its relatively lower costs, ease of maintenance, higher production spray rates, and significant economic benefits while spraying over large areas.

New processes and coating materials developed with suitable properties improve the functionality and application of arc-sprayed coatings in different environments. Besides focusing on arc-spraying parameters, developing high-performance and multifunctional coatings drive the flexibility of arc-spraying to achieve coatings with advanced properties [6,7]. Fe-based crystalline and amorphous coatings have great potential in anti-corrosion and anti-wear applications. They are also suitable candidates for medium- to high-temperature 
applications because of their good oxidation properties. The performance of Fe-based coatings relies on the coating structure, amorphous phase content, and chemical composition of the coatings [8]. The spraying parameters, such as the gas pressure and particle size of the cored powder, affect the coating structure. A dense coating structure with low porosity and grain boundaries enhances the coating performance in ambient and high-temperature conditions. Alloying elements with high glass-forming ability (GFA) can be added to the feedstock material to improve the amorphization of the coating. Ferrous matrices reinforced with particles such as $\mathrm{Al}_{2} \mathrm{O}_{3}, \mathrm{WC}$, TiC, and $\mathrm{Cr}_{3} \mathrm{C}_{2}$ improve the tribological and high-temperature properties [9]. Fe-based coatings form oxide scales as protective mechanisms against oxidation and corrosion in high-temperature conditions. $\mathrm{Xu}$ et al. [10] elevated the high-temperature properties of $\mathrm{FeAl}$ intermetallics by adding abrasive-resistant $\mathrm{Cr}_{3} \mathrm{C}_{2}$. $\mathrm{Cr}_{3} \mathrm{C}_{2}$ in the cored wire improved the coating bond strength and facilitated formation of $\mathrm{Cr}_{2} \mathrm{O}_{3}$ and $\mathrm{Al}_{2} \mathrm{O}_{3}$ oxides, which increased the high-temperature resistant properties. To enhance the high-temperature and corrosion properties, $\mathrm{Cr}$ is widely used in Ni-based and Fe-based alloys because it forms the protective $\mathrm{Cr}_{2} \mathrm{O}_{3}$ oxide layer [11]. Ni-based coatings are preferred due to their outstanding properties in high temperatures to prevent sulfidation and oxidation of the substrate. However, due to the high production cost, Fe-based coatings are increasingly being developed by adding alloying elements and ceramic particles to substitute the Ni-based coatings [8,12-14]. Fe-based coatings can replace Ni-based coatings because of good mechanical properties, low density, low cost, and availability of raw materials. Li et al. [12] prepared arc-sprayed $\mathrm{FeCrSiB}$ and observed that adding $\mathrm{Si}$ and $\mathrm{B}$ elements reduced the oxide inclusions and increased hardness in the coating compared with $\mathrm{NiCrTi}$ and FeCr. Table 1 shows a comparison of properties for arc-sprayed Fe-based and Ni-based coatings. Low porosity, high bonding strength, and hardness enhance the overall properties of Fe-based coatings. Hathaipat et al. [15] showed that arc-sprayed Fe-based alloys offer good intermediate properties as an alternative for the $\mathrm{NiAl}$ bond coat at temperatures below $400^{\circ} \mathrm{C}$. The rapid growth of cored wires technology has increased the metallurgical variety of Fe-based coatings. The material composition can be developed to suit the expected performance of the coatings. Fe-based amorphous/nanocrystalline coatings with high metallic glass content, dense structure, and low porosity have been fabricated using arc-spraying [16,17]. The amorphous coatings can be prepared by arc-spraying due to the rapid cooling process of about $\left(\sim 10^{5} \mathrm{Ks}^{-1}\right)$ that prevents crystallization and long-range diffusion [18]. The addition of glass-forming elements (such as B, P, C, Mo, and Si) can also generate a certain amount of amorphous content, which improves the hardness and toughness of the coating [19-21].

Table 1. Comparison of properties for arc-sprayed Ni-based and Fe-based coatings.

\begin{tabular}{|c|c|c|c|c|}
\hline \multirow[t]{2}{*}{ Fe-Based Coatings } & \multicolumn{3}{|c|}{ Coating Properties } & \multirow[t]{2}{*}{ References } \\
\hline & Hardness & Porosity & Bond Strength & \\
\hline $\mathrm{FeTi} / \mathrm{CrB}$ & 62.7 HRC $(\sim 805 \mathrm{HV})$ & $2.7 \%$ & $40.21 \mathrm{MPa}$ & [22] \\
\hline $\mathrm{FeCrB}$ & $\begin{array}{c}\text { 811.4 } \mathrm{HV}_{0.1}-920.1 \\
\mathrm{HV}_{0.1}\end{array}$ & $3.31 \%-4.01 \%$ & - & [23] \\
\hline $\mathrm{FeNiBCrSi}$ & $700-1025 \mathrm{HV}_{0.1}$ & - & $57 \mathrm{MPa}$ & [24] \\
\hline FeCrBSiNbW & $14.7 \mathrm{GPa}(\sim 1499 \mathrm{HV})$ & $2.8 \%$ & - & [25] \\
\hline FeNiCrBSiNbW & $850-1000 \mathrm{HV}_{0.1}$ & $1.8 \%$ & $52.1 \mathrm{MPa}$ & {$[26,27]$} \\
\hline FeCrNiNbBSiMo & - & $3.46 \%$ & $42.3 \mathrm{MPa}$ & [28] \\
\hline $\mathrm{FeAl}$ & $\begin{array}{c}6.47 \mathrm{GPa} \\
(\sim 659.7 \mathrm{HV})\end{array}$ & $1.83 \%$ & $24.5 \mathrm{MPa}$ & [29] \\
\hline $\mathrm{FeNiB}-\mathrm{Cr}_{3} \mathrm{C}_{2}$ & $1090 \mathrm{HV}_{0.1}$ & $2.1 \%$ & - & [30] \\
\hline $\mathrm{FeCrB}-\mathrm{Cr}_{3} \mathrm{C}_{2}$ & $860-1260 \mathrm{HV}_{0.1}$ & $2.33 \%$ & - & [31] \\
\hline $\mathrm{FeCr}$ & $480 \mathrm{HV}_{0.1}$ & $5.02 \%$ & - & [11] \\
\hline $\mathrm{FeCrSiB}$ & $650 \mathrm{HV}_{0.1}$ & $4.08 \%$ & - & [11] \\
\hline FeNiCrAl & $626 \mathrm{HV}_{0.1}$ & $8.76 \%$ & $52.3 \mathrm{MPa}$ & [32] \\
\hline 3Cr13/FeNiCrAl & $375-390 \mathrm{HV}_{0.1}$ & - & $45.7 \mathrm{MPa}$ & [33] \\
\hline Fe-Cr-B-C & 6.47 GPa ( 659.7 HV) & & - & \\
\hline
\end{tabular}


Table 1. Cont.

\begin{tabular}{|c|c|c|c|c|}
\hline \multirow[t]{2}{*}{ Ni-Based Coatings } & \multicolumn{3}{|c|}{ Coating Properties } & \multirow[b]{2}{*}{ References } \\
\hline & Hardness & Porosity & Bond Strength & \\
\hline $\mathrm{FeCrAl} / \mathrm{Ni} 95 \mathrm{Al}$ & $530 \mathrm{HV}_{0.1}$ & - & $43 \mathrm{MPa}$ & [34] \\
\hline NiCrMoAl & $\begin{array}{c}3.65 \pm 0.56 \mathrm{GPa} \\
(\sim 372.2 \mathrm{HV})\end{array}$ & $2.4 \%$ & - & [35] \\
\hline $\mathrm{Ni}-5 \mathrm{Al}$ & $290 \mathrm{HV}$ & $<2 \%$ & & [36] \\
\hline $\mathrm{Ni}-5 \mathrm{Al}$ & 203.8 HV \& 249 HV & $1.55 \%-1.58 \%$ & - & {$[37]$} \\
\hline $\mathrm{Ni}-20 \mathrm{Cr}$ & $273.5 \mathrm{HV} \& 379.8 \mathrm{HV}$ & $1.53 \%-1.54 \%$ & - & [37] \\
\hline $\mathrm{NiCrTi}$ & $380 \mathrm{HV}_{0.1}$ & $2.49 \%$ & - & [11] \\
\hline $\mathrm{Ni}-30 \mathrm{Cr}$ & $244 \pm 12 \mathrm{HV}_{0.3}$ & $8.4 \%$ & & \\
\hline $\mathrm{Ni}-45 \mathrm{Cr}$ & $242 \pm 11 \mathrm{HV}_{0.3}$ & $5.0 \%$ & - & [38] \\
\hline $\mathrm{Ni}-50 \mathrm{Cr}$ & $209 \pm 7 \mathrm{HV}_{0.3}$ & $6.1 \%$ & & \\
\hline
\end{tabular}

This review presents the current research status and developments of the arc-sprayed Fe-based coatings. We discussed the wear behavior, corrosion analysis, and high-temperature resistant properties of Fe-based coatings. The protection mechanisms against wear, corrosion, and high-temperature conditions are elaborated.

\section{Working Principle of the Arc-Spraying Process}

The arc-spraying process melts wires with an electric arc formed at the tip, and the molten or semi-molten materials propelled by a stream of high-pressure velocity gas onto a substrate material to form the coating (Figure 1) [39]. Air, $\mathrm{N}_{2}$, and $\mathrm{CO}_{2}$ are some of the atomizing gases used in the spraying process. The arc-spraying set-up consists of compressed gas supply, wire feed, arc-spray gun, spray controller, and power supply. The coating formed results from the overlapping splats that interlock and build on top of one another with a cooling rate of $\sim 10^{5} \mathrm{~K} / \mathrm{s}$ [40]. Molten particles from the electrode tips can reach a temperature of up to $4000-6000{ }^{\circ} \mathrm{C}$; the particles are accelerated toward the substrate surface by an atomizing gas with pressure in the range of $0.27-0.6 \mathrm{MPa}$; the velocity of particles $<300 \mathrm{~m} / \mathrm{s}$. Coatings obtained have high adhesion strength of approximately $28-41 \mathrm{MPa}$ and porosity levels of around 3-10\%, but this has been improved over time by the formation of amorphous/nanocrystalline coatings and addition of reinforcement particles as shown in Tables 1 and 2 [39]. In comparison with arc-spraying, high-velocity arc-spraying (HVAS) provides the molten particles with a higher atomizing air pressure and velocity, which improves the quality of the coatings [41,42].

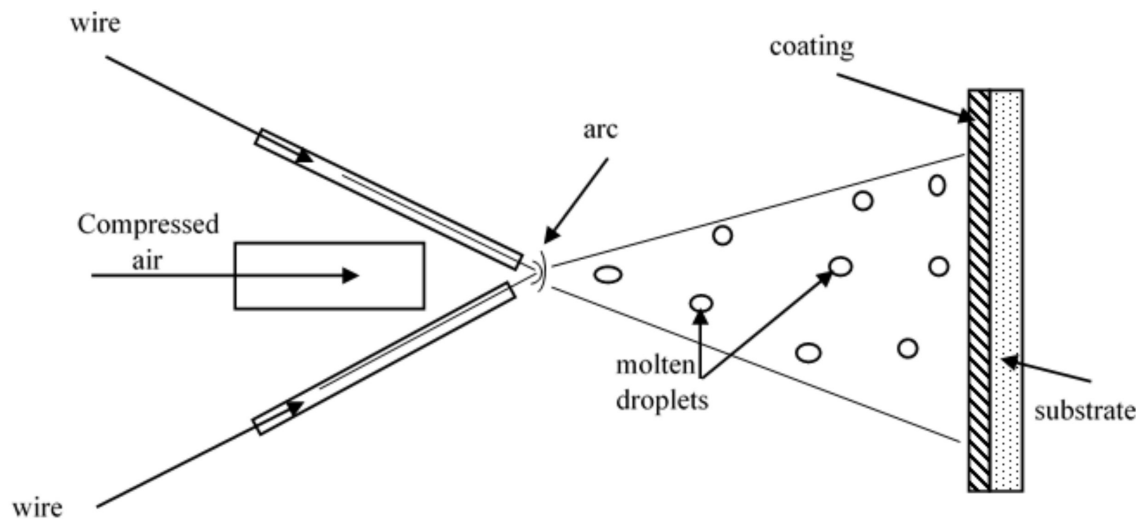

Figure 1. Illustration of the arc-spraying process.

\subsection{Coating Material Preparation}

The arc-spraying process uses alloy metal wires and cored wires to prepare coatings. Coatings prepared by alloy metallic materials include: $\mathrm{CuAl}, \mathrm{ZnAl}, \mathrm{AlMg}$, and $\mathrm{NiAl}$. However, alloy wires are limited due to the few ductile materials and the high hardening 
tendency of metal alloys during the drawing process. Cored wires contain powdered particles inside a sheath of ductile metal or alloy as illustrated in Figure 2. They are beneficial because of their lower cost, shorter production cycle, and combined benefits of the metals and powder materials. They provide diverse options for arc-spraying materials. High hardness materials (oxides, carbides, and nitrides) added into the metal sheath improves the wear and high-temperature resistance of the coatings. The filling factor coefficient, which is the ratio of the core weight to the total weight of the core, determines the material amount in the core. Depending on the diameter of wire, density of core material, and purpose, the filling factor ranges between 15 and $40 \%$ [43].

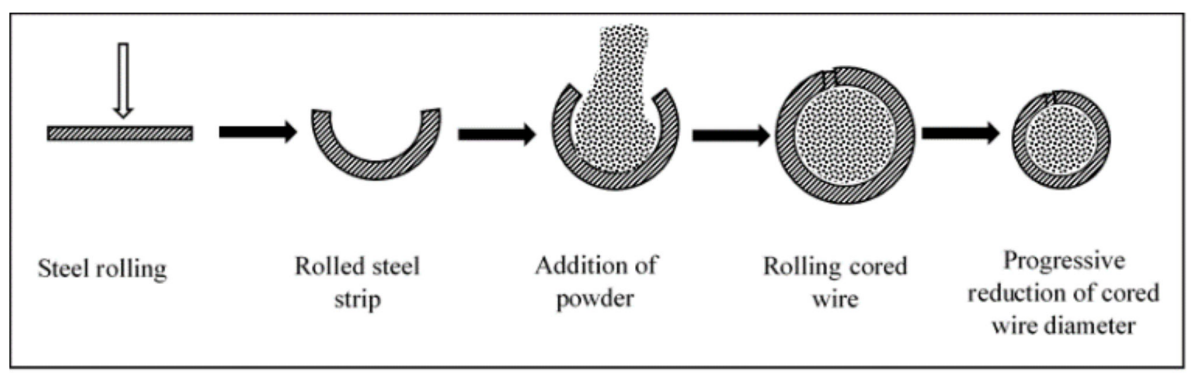

Figure 2. Schematic diagram of cored wire preparation. Reprinted with permission from ref. [44]. Copyright 2007 Elsevier.

\subsection{Arc-Sprayed Coating Microstructure}

Upon impact on the substrate, molten droplets flatten and solidify to form splats that accumulate and build up the coating. These coatings are characterized by a lamellar structure with alternating layers (Figure 3). Studies have shown the correlation between the operating spray parameters (spray distance, current, arc voltage, and atomizing gas pressure) and the microstructural and mechanical properties of arc-sprayed coatings, hence the need for optimization of spray parameters [45-49]. Pores, oxide inclusions, unmelted particles, and cracks may also be present due to some coating imperfections. A high porosity and oxide content reduce the quality of the coatings. As discussed by Li et al. [50], pores in the coating can be generated as a result of the following: air traps in the molten particles during the solidification process; some splats form zonal fractures along the boundaries because of incomplete accumulation of the flat particles; and, during the solidification of the molten droplets, the density difference between the solid and liquid phases of the droplets leads to volumetric shrinkage. Pores can be beneficial to the coating structure because they reduce the friction during the oil wear test by acting as storage structures for oil. The pores, however, should be kept as minimal as possible. In corrosive environments, pores link the corrosion media to the coating, damaging the underlying coating and substrate. Porosity can be effectively reduced by post-coating techniques such as sealing, heat treatment, and laser remelting [46,51]. Oxides found in the coating have been explained as occurring in three different ways [52]: the primary droplets are oxidized during the atomization process as in-flight particles; the secondary droplets are oxidized from splashing; and the coating surface is oxidized after deposition. In some cases, oxides can be beneficial to the coating properties. As stated by $\mathrm{Xu}$ et al. [10], the small oxide particles in the $\mathrm{FeAl} / \mathrm{Cr}_{3} \mathrm{C}_{2}$ coating structure enhanced the abrasion resistance, erosion resistance, and bonding strength. 


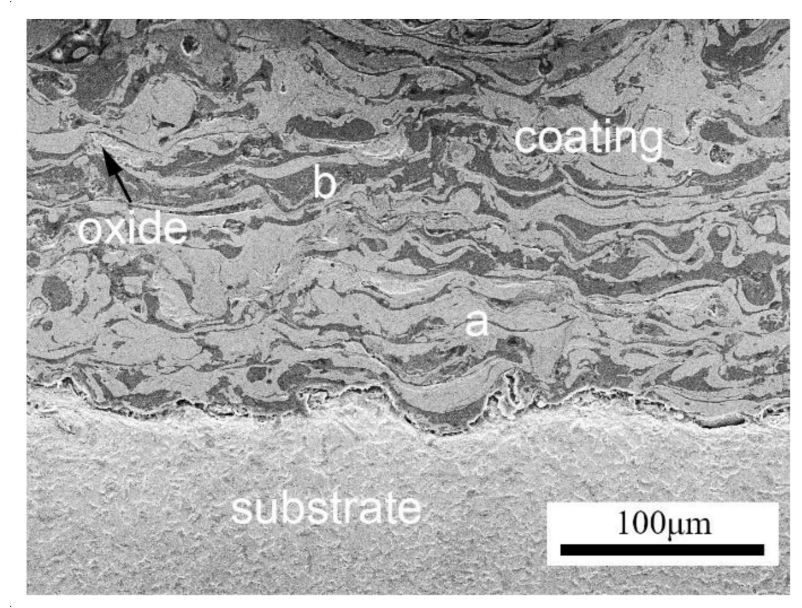

Figure 3. HVAS FeCrAl/ Al coating microstructure: (a) FeCrAl splats and (b) Al splats. Reprinted with permission from ref. [53].

\section{Properties of Arc-Sprayed Fe-Based Coatings}

\subsection{Wear Properties at Room Temperature}

Of the many reasons for material failure, wear causes structural degradation. But, the high hardness, fracture toughness, and good adhesion strength properties increase the wear-resistance of Fe-based alloy coatings in their potential applications. For both wear tests carried out on the pin-on-disc and abrasive wheel testers, the sliding wear behavior of thermal-sprayed coatings could improve by adding hard phases of wearresistant particulates such as $\mathrm{Cr}_{3} \mathrm{C}_{2}, \mathrm{WC}$, and $\mathrm{TiB}_{2}$ into the powder matrix of cored wires, and increasing amorphous phase content in the coating [20,54]. Table 2 summarizes the wear properties of some Fe-based coatings.

Ding et al. [55] improved the wear properties of arc-sprayed $\mathrm{FeCrNi} / \mathrm{CBN}$ coatings by adding the hard phase CBN powder during cored wire preparation. The diffused CBN particles presented hard phases, which improved the wear resistance of the coatings by protecting the substrate and controlling the abrasion wear of the coating. Arc-sprayed FeCrBSiNbW coating [25] had an amorphous/nanocrystalline structure with low porosity, dense structure, and high microhardness that improved the wear resistance. The wear resistance of the amorphous coating was better than that of $3 \mathrm{Cr} 13$ coating in the same oil-lubricated wear test conditions because of the homogenously dispersed amorphous particles in the glassy phase. The wear resistance increased due to the composite microstructure of the amorphous coating that reduced volume loss attributed to the plasticity and the restriction of cracking of the amorphous phase [21]. Fu et al. [30] compared the wear properties of arc-sprayed Fe-based amorphous coatings filled with $\mathrm{NiB}$ and $\mathrm{NiB}-\mathrm{Cr}_{3} \mathrm{C}_{2}$ powders. The wear resistance of both coatings was better than that of Q235 steel substrate. The higher wear resistance of $\mathrm{NiB}-\mathrm{Cr}_{3} \mathrm{C}_{2}$ was due to the net structure formed by the nanocrystalline particles. The even distribution of the hard boride phase in the metal matrix promoted the high hardness. The wear resistance of $\mathrm{NiB}$ was lower than that of $\mathrm{NiB}-\mathrm{Cr}_{3} \mathrm{C}_{2}$ coating because of the higher porosity and presence of oxides that formed microcracks under abrasion conditions. In amorphous coatings, the wear resistance of the coatings depends on the coating microstructure and the primary phases. Arc-sprayed Fe-based coating with $\mathrm{CrB}$ and $\mathrm{Cr}_{3} \mathrm{C}_{2}$ filler powders were similarly prepared by $\mathrm{Fu}$ et al. [31]. The coatings contained rich amorphous phase content with a bit of nanocrystalline structure. The amorphous phase formed due to the high cooling rates of the droplets $\left(\sim 10^{5} \mathrm{~K} / \mathrm{s}\right)$ and the high glass-forming ability (GFA) of the composition of cored wires [56]. The amorphous phase transformed into nano crystallites, improving the microhardness. The decreased grain size increases microhardness in nanostructured materials because of the higher density of the coating, which prevents the propagation of dislocations and improves the plastic deformation resistance [57]. Nano crystallites formed during the spraying process due to 
the amorphous phase devitrifying when substrate temperatures increased. The Fe-based coating had eight times higher relative wear resistance than the commercial $3 \mathrm{Cr} 13$ coating. The micro-cutting wear mechanism of the amorphous coating was minimized due to its higher microhardness and the existence of $\mathrm{Fe}_{3} \mathrm{O}_{4}$ lamellae that contributed to the flaking off of the coating. Cheng et al. [58,59] prepared wire arc-sprayed FeBSiCrNbMnY amorphous coatings. Compared with the $3 \mathrm{Cr} 13$ coating, the amorphous coatings had a better wear resistance. The dense, compact structure, low porosity, high hardness, and the dispersion strengthening of nanocrystalline grains of the amorphous coating minimized the material removal, hence the excellent wear resistance. The amorphous coating exhibited high hardness to modulus of elasticity ratio $(H / E)$, which has a positive influence on the wear properties of the coating [60]. The high wear resistance of the coating was attributed to the effect of the nanocrystalline particles and amorphous phase. The nanocrystalline particles of coatings contain few defects, as stated in [61], hence their high strength and resistance to abrasive wear.

Table 2. Summary of the wear and mechanical properties of the arc-sprayed Fe-based coatings.

\begin{tabular}{|c|c|c|c|c|c|c|}
\hline Coating & Porosity & Hardness (H) & $\begin{array}{c}\text { Elastic } \\
\text { Modulus } \\
(\mathrm{GPa})\end{array}$ & $H / E$ & $\begin{array}{l}\text { Specific Wear } \\
\text { Rate }\end{array}$ & Wear Mechanism \\
\hline FeCrBSiNbW & $2.8 \%$ & $\begin{array}{c}14.7 \mathrm{GPa} \\
(\sim 1499) \mathrm{HV}\end{array}$ & 198 & 0.074 & - & $\begin{array}{l}\text { Dispersion strengthening of } \\
\text { the } \\
\text { amorphous/nanocrystalline } \\
\text { grains prevent the material } \\
\text { removal [25] }\end{array}$ \\
\hline $\begin{array}{c}\mathrm{Fe}-\mathrm{NiB} \\
\mathrm{Fe}-\mathrm{NiB}-\mathrm{Cr}_{3} \mathrm{C}_{2}\end{array}$ & $\begin{array}{l}2.7 \% \\
2.1 \%\end{array}$ & $\begin{array}{c}950 \mathrm{HV}_{0.1} \\
1090 \mathrm{HV}_{0.1}\end{array}$ & - & - & - & $\begin{array}{l}\text { Wear mechanism of the } \\
\text { coatings was by flaking off } \\
\text { and some slight plastic } \\
\text { furrows [30] }\end{array}$ \\
\hline $\mathrm{Fe}-\mathrm{CrB}-\mathrm{Cr}_{3} \mathrm{C}_{2}$ & $2.33 \%$ & $860-1260 \mathrm{HV}_{0.1}$ & - & - & - & $\begin{array}{l}\text { High hardness prevented } \\
\text { micro-cutting. Mass loss by } \\
\text { flaking mechanism [31] }\end{array}$ \\
\hline $\mathrm{FeBSiNb}$ & $1.2 \%$ & $\begin{array}{l}16.42 \mathrm{GPa} \\
(\sim 1674) \mathrm{HV}\end{array}$ & 219 & 0.075 & & Brittle failure and fracture [62] \\
\hline FeBSiCrNbMnY & $1.7 \%$ & $\begin{array}{c}15.7 \mathrm{GPa} \\
(900-1050) \\
\mathrm{HV}_{0.1}\end{array}$ & 217 & 0.07 & - & $\begin{array}{l}\text { Brittle failure and fracture } \\
\qquad[58,59]\end{array}$ \\
\hline $3 \mathrm{Cr} 13$ & & $\begin{array}{l}6.9 \mathrm{GPa} \\
(\sim 704) \mathrm{HV}\end{array}$ & 199 & 0.035 & - & $\begin{array}{l}\text { Big pits and parallel grooves } \\
\text { characterize cutting and } \\
\text { delamination [63] }\end{array}$ \\
\hline FePSiBNb & $<3 \%$ & $\begin{array}{l}12.3 \mathrm{GPa} \\
(\sim 1254) \mathrm{HV}\end{array}$ & 204 & 0.06 & $\begin{array}{c}(0.57-1.86) \times \\
10^{-5} \mathrm{~mm}^{3} / \mathrm{Nm} \\
\text { (at different } \\
\text { loads and } \\
\text { sliding speeds) }\end{array}$ & $\begin{array}{l}\text { Oxidative wear coupled with } \\
\text { delamination [63] }\end{array}$ \\
\hline $\begin{array}{c}\text { Fe-FeB- } \\
\text { WC/12Co } \\
\text { Fe-FeB- } \\
\text { WC/12Ni }\end{array}$ & $\begin{array}{l}2.1 \% \\
3.2 \%\end{array}$ & $\begin{array}{l}920 \mathrm{HV}_{0.1} \\
872 \mathrm{HV}_{0.1}\end{array}$ & - & - & 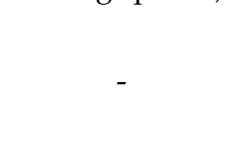 & $\begin{array}{l}\text { Selective removal of the binder } \\
\text { caused by plastic deformation } \\
\text { and fatigue [64] }\end{array}$ \\
\hline $\begin{array}{l}\text { FeCrCMoBWSiNb } \\
\quad(140 \mathrm{MXC})\end{array}$ & $1.55 \%$ & $\begin{array}{l}9.1 \mathrm{GPa} \\
(\sim 928) \mathrm{HV}\end{array}$ & - & & - & $\begin{array}{l}\text { Delamination in combination } \\
\text { with plastic deformation and } \\
\text { oxidation [21] }\end{array}$ \\
\hline FeNiCrBCSi & $2.1 \%$ & $960 \mathrm{HV}_{0.3}$ & - & - & - & $\begin{array}{l}\text { Selective removal of the binder } \\
\text { is probably caused by the } \\
\text { plastic deformation and } \\
\text { fatigue, Flaking off caused by } \\
\text { microcracks [ } 51]\end{array}$ \\
\hline 08Mn2Si & $6.12 \%$ & $231.2 \mathrm{HV}$ & & & & \\
\hline $4 \mathrm{Cr} 13$ & $3.33 \%$ & $288.9 \mathrm{HV}$ & - & - & - & Abrasive wear [50] \\
\hline $65 \mathrm{Mn}$ & $5.43 \%$ & $329.9 \mathrm{HV}$ & & & & \\
\hline
\end{tabular}


Table 2. Cont.

\begin{tabular}{|c|c|c|c|c|c|c|}
\hline Coating & Porosity & Hardness (H) & $\begin{array}{l}\text { Elastic } \\
\text { Modulus } \\
(\mathrm{GPa})\end{array}$ & $H / E$ & $\begin{array}{c}\text { Specific Wear } \\
\text { Rate }\end{array}$ & Wear Mechanism \\
\hline FeCrMnMoWBCSi & $4.85 \%$ & $883.8 \mathrm{HV}_{0.1}$ & & & - & $\begin{array}{l}\text { Fatigue wear and oxidation } \\
\text { wear [65] }\end{array}$ \\
\hline FeCrBSiMnMoW & $2.53 \%$ & $1150 \mathrm{HV}_{0.3}$ & - & - & $\begin{array}{l}3.3 \times 10^{-5} \\
\mathrm{~mm}^{3} / \mathrm{Nm}\end{array}$ & $\begin{array}{l}\text { Abrasive wear mechanism } \\
\text { with brittle peeling pit and } \\
\text { cracks [66] }\end{array}$ \\
\hline $\begin{array}{c}\text { FeNiCrAl- } \\
\text { BRE/Ni95Al }\end{array}$ & $3.74 \%$ & $480-600 \mathrm{HV}_{0.1}$ & - & - & - & $\begin{array}{l}\text { Fracture of splats due to } \\
\text { severe plastic deformation at } \\
\text { the tip of splats. Cracks } \\
\text { initiated at the edges of pores, } \\
\text { between the boundaries of } \\
\text { inclusions and splats or } \\
\text { interfaces of splats [67] }\end{array}$ \\
\hline $\mathrm{FeNiCrAl} / 3 \mathrm{Cr} 13$ & - & $375-390 \mathrm{HV}_{0.1}$ & - & - & $1.963 \mathrm{~mm}^{3} / \mathrm{Nm}$ & Abrasive wear mechanism [33] \\
\hline $\begin{array}{l}\text { WC/W2C- } \\
\text { FeCMnSi }\end{array}$ & $\begin{array}{l}5.4 \% \\
4.4 \% \\
2.7 \% \\
2.9 \% \\
3.3 \%\end{array}$ & $\begin{array}{c}567 \pm 63 \mathrm{HV}_{0.3} \\
543 \pm 86 \mathrm{HV}_{0.3} \\
561 \pm 79 \mathrm{HV}_{0.3} \\
585 \pm 117 \\
\quad \mathrm{HV}_{0.3} \\
630 \pm 65 \mathrm{HV}_{0.3}\end{array}$ & $\begin{array}{c}84.0 \\
81.9 \\
118.3 \\
124.8 \\
151.4\end{array}$ & $\begin{array}{l}0.057 \\
0.055 \\
0.051 \\
0.042 \\
0.051\end{array}$ & 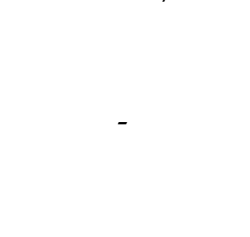 & [45] \\
\hline $\mathrm{FeBSiNbCrMo}$ & $1.1 \%$ & $\begin{array}{l}18.7 \mathrm{GPa} \\
(\sim 1907) \mathrm{HV}\end{array}$ & - & - & - & Brittle delamination [68] \\
\hline $\mathrm{FeBSiNbCr}$ & $1.5 \%$ & $1113 \mathrm{HV}$ & - & - & - & $\begin{array}{l}\text { Brittle breaking and fracture } \\
\text { [69] }\end{array}$ \\
\hline
\end{tabular}

Post-treatment coating techniques such as annealing, surface remelting, and sealing improve the wear resistance of Fe-based coatings. FeNiCrAl coatings were surface-remelted by the tungsten inert gas welding. The wear resistance improved as a result of the reduced pores and cracks. The main abrasive mechanism was cutting and ploughing [70]. The wear resistance of the Fe-based amorphous coatings was enhanced by heat treatment. Fu et al. [51] obtained high wear resistance of the heat-treated Fe-based amorphous coatings due to the increased hardness caused by precipitates that formed during sintering. Yan et al. [65] described the wear properties of arc-sprayed FeCrMnMoWBCSi amorphous alloy coatings after sealing with aluminum phosphate. The sealing agent improved the wear resistance by filling coating defects and hindering crack propagation.

Transition layers or bond coat layers improve the thermal shock resistance and wear resistance by enhancing the bonding strength [71]. FeNiCrAlBRE/Ni95Al was arc-sprayed with Ni95Al applied as a transition layer to improve the adhesive strength between the coating and substrate. The coating had better wear resistance because of the low debris and shallow grooves [67]. Tian et al. [33] reported the abrasive wear properties of the 3Cr13 coating when FeNiCrAl was applied as a transition layer between the coating and the substrate. The low wear volume loss of the composite coating was due to its high hardness caused by evenly distributed $\mathrm{Cr}_{23} \mathrm{C}_{6}$ and (Fe, $\mathrm{Cr}$ ) phase. The hardness-wear resistance relation could be explained by Archard's Equation [72], as shown in Equation (1):

$$
V_{W}=K \times \frac{S N}{H}
$$

where $V_{W}$ is the worn volume, $K$ is the wear coefficient, $S$ is the sliding wear distance, $N$ is the applied load, and $H$ is the hardness.

According to Equation (1), it can be stated that the high coating hardness contributes to the good wear properties. The wear rate of the coating is proportional to the applied load and sliding distance (sliding time and sliding linear speed) [73]. Volume wear losses 
of the AISI 45 steel substrate and the metallic glass coatings increased linearly with sliding distance (Figure 4).

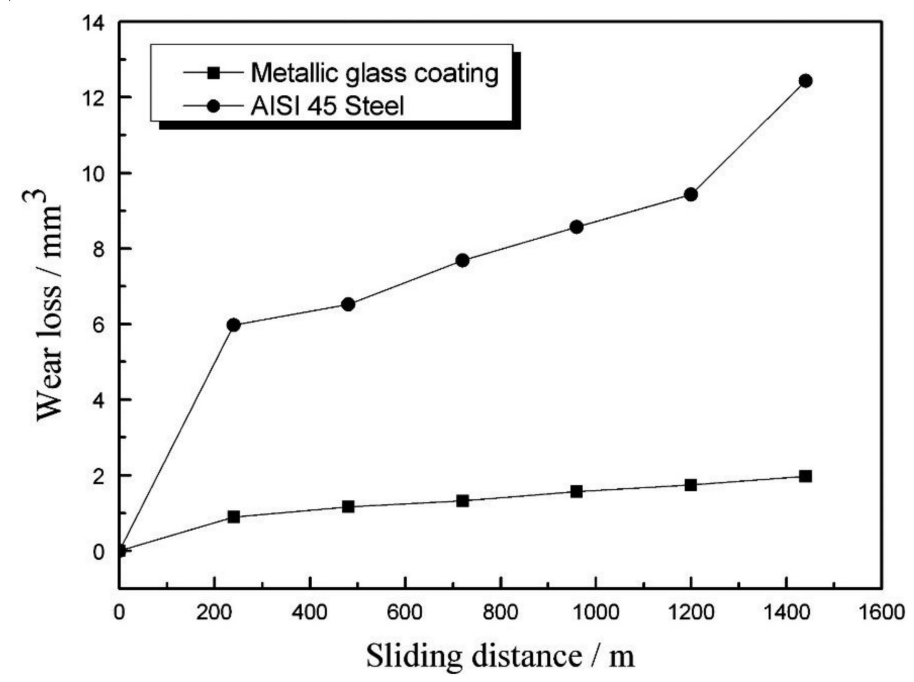

Figure 4. Wear losses of coating and substrate as a function of sliding distance. Reprinted with permission from ref. [74]. Copyright 2013 Elsevier.

It is increasingly being recognized that hardness is not the only primary requirement for wear resistance. Researchers have recently examined the effects of elastic modulus on the wear resistance properties. The induced residual stress and mechanical strength of the coating depend on the elastic modulus. The low elastic modulus and high coating hardness contribute to high wear resistance and elastic energy absorption ability [60]. The microhardness and elastic modulus relationship can be derived from the load-displacement curves data by nanoindentation measurement. The ultra-high strength of the amorphous structure and excellent bonding between the elements improves the coating hardness. $H / E$ shows the depth of penetration that a coating material tolerates without exceeding the elastic limit. A high hardness to elastic modulus $H / E$ ratio indicates good wear resistance of the arc-sprayed coatings. A high $H^{3} / E^{2}$ indicates the resistance of the loaded material to plastic deformation and therefore shows that the material has high toughness $[75,76]$. Figure 5 shows a relationship of the hardness elastic modulus for the Q235 steel and three metallic glass coatings. The $H / E$ and $H^{3} / E^{2}$ increased after addition of $\mathrm{Cr}$ and Mo elements promoting lower friction and higher wear resistance [68]. The higher value of $H / E$ and $\mathrm{H}^{3} / \mathrm{E}^{2}$ shows that the ability to absorb applied deformation is strong without exceeding the elastic limit, or adapting to the deformation with less damage [63].
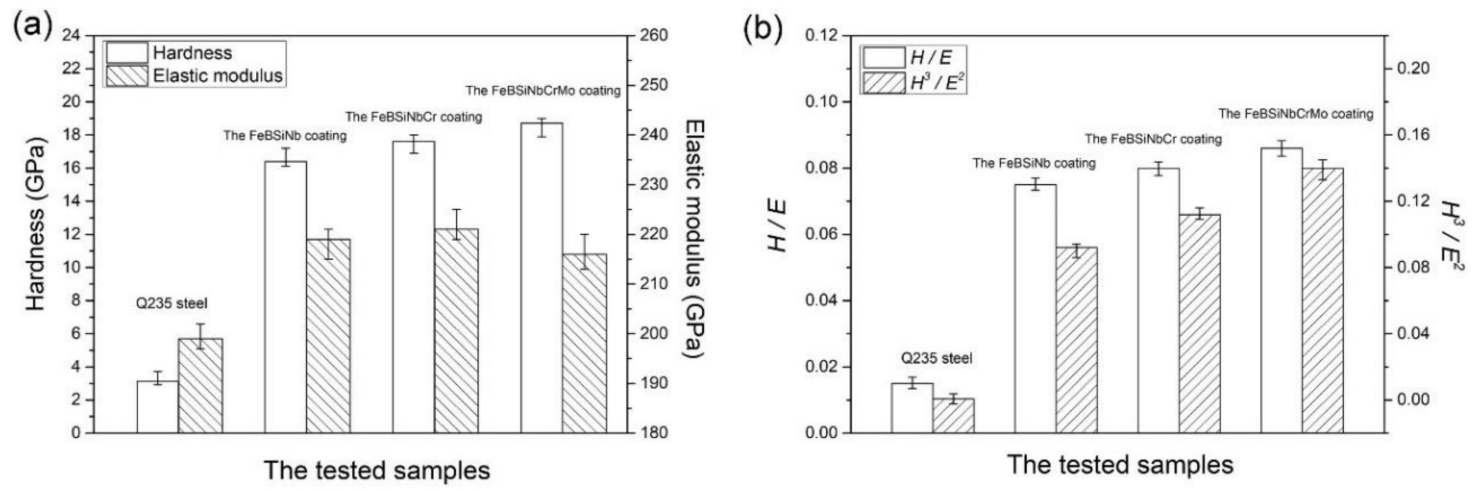

Figure 5. (a) Hardness $H$ and elastic modulus $E,(\mathbf{b}) H / E$ and $H^{3} / E^{2}$ of the samples. Reprinted with permission from ref. [68]. Copyright 2018 Elsevier. 
In summary, the wear properties of the Fe-based coatings depend on the coating microstructure, the additional hard reinforcement particles, and the mechanical properties, including hardness and elastic properties. Similarly, the amorphous/nanocrystalline phase structure of the coatings improves wear resistance as a result of the dispersion strengthening effect caused by the homogenous amorphous phase in the glassy state. Further research should be conducted to improve the tribological properties of arc-sprayed Fe-based amorphous coatings by adding reinforcement particles such as $\mathrm{WC}, \mathrm{Cr}_{3} \mathrm{C}_{2}$, and $\mathrm{Al}_{2} \mathrm{O}_{3}$.

\subsection{Corrosion Properties at Room Temperature}

Corrosion is among the leading causes of degradation of materials, especially equipment and structures exposed to marine environments. Coating defects such as pores and cracks have adverse impacts on the corrosion properties. They act as passages for the corrosive media, and they should be minimized in the coating microstructure. Lin et al. [26] compared the corrosion properties of arc-sprayed $\mathrm{FeB}, \mathrm{FeBSi}$, and $\mathrm{FeNiCrBSiNbW}$ coatings. The compact structure with low porosity and amorphous/nanocrystalline structure of the $\mathrm{FeNiCrBSiNbW}$ coating offered superior corrosion protection in $3.5 \mathrm{wt} . \% \mathrm{NaCl}$ solution as summarized in Table 3. The $\mathrm{Cr}$ element formed a passivation film, which further enhanced corrosion protection. The absence of the coating defects in the amorphous/nanocrystalline coating improved the corrosion resistance. Pores and cracks resulted in crevice corrosion after exposure to the electrolyte [77]. Arc-sprayed $\mathrm{FeCrBSiNbW}$ amorphous coatings displayed better corrosion resistance than $0 \mathrm{Cr} 18 \mathrm{Ni} 9$ coatings under the same testing conditions [25]. The structural and chemical homogeneity of the amorphous coating slowed the electrolyte penetration through the coating. The presence of oxides, microcracks, and semi-molten particles in the $0 \mathrm{Cr} 18 \mathrm{Ni}$ s stainless steel coating facilitated the higher corrosion rate.

Table 3. Summary of the corrosion properties of Fe-based coatings.

\begin{tabular}{|c|c|c|c|c|}
\hline Coatings & Substrate & $\begin{array}{c}\text { Current Densities } \\
I_{\text {corr }}\left(\mu \mathrm{A} / \mathrm{cm}^{2}\right)\end{array}$ & $\begin{array}{c}\text { Current Potential } \\
E_{\text {corr }}(\mathrm{V})\end{array}$ & Corrosion Behavior \\
\hline $\begin{array}{c}\text { 0Cr18Ni9 } \\
\text { FeCrBSiNbW }\end{array}$ & AISI 1045 Steel & $\begin{array}{c}32.6 \\
4.3\end{array}$ & $\begin{array}{l}-0.68 \\
-0.45\end{array}$ & $\begin{array}{l}\text { Chemical and structural homogeneities of } \\
\text { the amorphous coating with a dense } \\
\text { structure and low porosity prevent } \\
\text { electrolyte penetration. Absence of } \\
\text { defects, grain boundaries, precipitates, } \\
\text { and segregation. The ability of Cr to form } \\
\text { a protective film [25]. }\end{array}$ \\
\hline $\begin{array}{c}\text { FeB } \\
\text { FeBSi } \\
\text { FeNiCrBSiNbW }\end{array}$ & AISI 1045 steel & $\begin{array}{c}18.96 \\
12.69 \\
8.72\end{array}$ & $\begin{array}{l}-0.758 \\
-0.738 \\
-0.447\end{array}$ & $\begin{array}{l}\text { Dissolution of Cr to produce a rich } \\
\text { passive film, homogenous } \\
\text { amorphous / nanocrystalline, compact } \\
\text { structure with low porosity and low oxide } \\
\text { content which improved corrosion } \\
\text { resistance of the coating [26]. }\end{array}$ \\
\hline $\begin{array}{c}\text { FeBSiNb } \\
\text { FeBSiNbCr } \\
\text { FeBSiNbCrMo }\end{array}$ & Q235 Steel & $\begin{array}{l}5.92 \\
3.61 \\
1.53\end{array}$ & $\begin{array}{l}-0.847 \\
-0.802 \\
-0.775\end{array}$ & $\begin{array}{l}\text { Corrosion resistance is attributed to its } \\
\text { glassy structure and chemical } \\
\text { compositions. The lower porosity and the } \\
\text { formation of chromium-rich oxide and } \\
\text { Mo-rich passive film. Addition of Mo } \\
\text { facilitates the passivation of Cr films [68]. }\end{array}$ \\
\hline
\end{tabular}

Post-treatment techniques such as annealing and sealing treatment affect the corrosion properties. Zeng et al. [46] studied the effect of atomizing gas type and sealing treatment on arc-sprayed stainless steel coating. Concerning corrosion properties, nitrogen-atomized coatings were more reliable than air-atomized coatings because of their denser structure, whereas sealed coatings provided better protection to the substrate against corrosion. Annealing amorphous coatings degraded the corrosion resistance due to the increasing 
amount of crystallization [78]. Annealing $\mathrm{FeNiCrBSiNbW}$ coating at different temperatures $\left(450,550\right.$, and $\left.650^{\circ} \mathrm{C}\right)$ reduced the corrosion resistance [79]. With the increase in annealing temperature, the corrosion potentials $\left(E_{\text {corr }}\right)$ reduced and the current densities $\left(I_{\text {corr }}\right)$ increased, as represented in Figure 6. The electrochemical impedance spectroscopy (EIS) of the as-sprayed coating displayed the largest size of the capacitive semicircle, hence the lowest corrosion rate (Figure 6). The amorphous phase of the coatings transformed into crystalline phase affecting the corrosion resistance. The amorphous phase in the arc-sprayed coating increased corrosion resistance due to the absence of dislocations and grain boundaries. In addition, the $\mathrm{Cr}$ element in the arc-sprayed FeNiCrBSiNbW coating formed passive films that improved corrosion resistance.
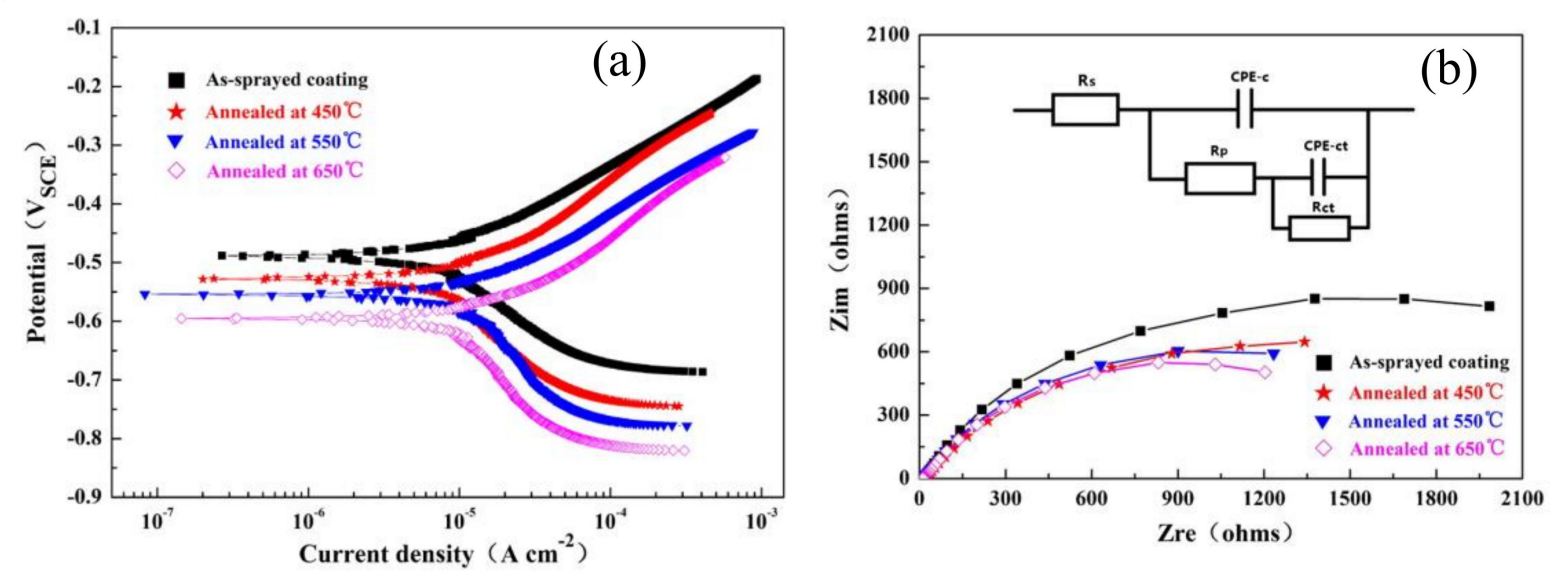

Figure 6. (a)Tafel polarization curves and (b) fitted EIS data of the as-sprayed and annealed FeNiCrBSiNbW coating. Reprinted with permission from ref. [79]. Copyright 2014 Taylor \& Francis.

Cheng et al. [80] studied the effect of crystallization on corrosion performance of arc-sprayed $\mathrm{FeBSiNb}$ coatings that were devitrified at different annealing temperatures $\left(500,550,600\right.$, and $\left.650^{\circ} \mathrm{C}\right)$. The Nyquist plots of the as-sprayed coating showed a larger diameter of the impedance spectra, which decreased with an increasing fraction of crystallization. The lack of defects in the microstructure and chemical homogeneity of the as-sprayed coating resulted in excellent corrosion properties. The crystallization of the amorphous coating led to lattice mismatch and strain, which made the stress caused by the heterogeneity weaken the cohesion between the oxide film and metal, thus causing film rupture. The annealing process caused the generation of structural defects such as intersplat oxides that dissolved forming pores and cracks that allowed electrolyte penetration. Table 3 summarizes the corrosion behavior of arc-sprayed Fe-based coatings.

In summary, the coating microstructure needs to be free of defects such as pores, oxides, unmelted particles, and cracks that accelerate the passage of electrolytes into the underlying coating. Oxides formed during the spraying process also degrade the corrosion resistance by reducing the adhesive strength between the coating splats. These defects can be minimized by optimizing the arc-spraying parameters. Crystallization of amorphous coatings during annealing causes lattice mismatch and strain, which weakens the coherence between the oxide films and metal, leading to the rupture of oxide films [81]. Thus, the annealing temperature and time should be controlled to obtain the optimum properties. Although some research has been carried out on the corrosion behavior of annealed Febased amorphous coatings, there is very little discussion about the corrosion behavior of annealed Fe-based crystalline alloys.

\subsection{High-Temperature Properties of Arc-Sprayed Fe-Based Coatings}

High-temperature wear, corrosion, erosion, and oxidation reduce the service life of components used in high-temperature environments. Steam pipes in geothermal power stations and boiler tubes are examples of structures that degrade due to hot corrosion and 
oxidation conditions. Boiler tubes in thermal power plants are exposed to fly ash particles on impact that result in high-temperature erosion. Arc-sprayed coatings have been applied due to their excellent performance in withstanding corrosion, wear, and erosion at elevated temperatures [37]. Change in the cored wires' material composition by filling powder containing carbides $\left(\mathrm{WC}, \mathrm{Cr}_{3} \mathrm{C}_{2}\right)$ or oxides $\left(\mathrm{Al}_{2} \mathrm{O}_{3}, \mathrm{Cr}_{2} \mathrm{O}_{3}\right)$ improves the service life of structures under high temperatures.

\subsubsection{High-Temperature Oxidation Behavior}

From previous works, the coating microstructure, oxidation processes, and phase transformation affect the oxidation resistance of arc-sprayed coatings [8]. Similar to corrosion and wear properties, defects such as coating-substrate delamination, cracks, and porosity are also detrimental to the oxidation resistance. Oxidation resistance in Fe-based coatings has been improved by adding elements such as $\mathrm{Cr}, \mathrm{Si}, \mathrm{Al}$, which form highly protective oxide scales at high temperatures. The effect of coating imperfections on the high-temperature oxidation of coatings has not been widely researched, and this could be a future topic of interest for arc-sprayed coatings. Li et al. [12] studied the oxidation properties of $\mathrm{FeCrB}(\mathrm{CSi})$ coatings with different chromium concentrations. The increase in the $\mathrm{Cr}$ content $(17,21,25$ at. \%) improved the high-temperature oxidation resistance due to the formation of a protective $\mathrm{Cr}_{2} \mathrm{O}_{3}$ oxide layer that inhibited further oxygen penetration. The coating with the highest amount of $\mathrm{Cr}$ ( 25 at. \%) had the least weight gain compared with the uncoated steel substrate and commercial FeCrAl coating. Boron and silicon elements controlled the oxidation of molten particles, thereby preventing $\mathrm{Cr}$ consumption. Li et al. [82] also investigated the influence of $\mathrm{Cr}$ content $(15,20,25,30,35,40$ at. \%) on the high-temperature oxidation properties of $\mathrm{Fe}-\mathrm{Cr}$ and compared with $\mathrm{Ni}-\mathrm{Cr}$-Ti coatings to determine the suitability of Fe-based coatings as substitutes for Ni-based coatings. The FeCr coatings had better high-temperature oxidation resistance than the SA213-T2 substrate used in boiler tubes. The thickness of the oxide scales and final weight gain of the $\mathrm{Fe}-\mathrm{Cr}$ coatings decreased with an increase in the $\mathrm{Cr}$ content at $650{ }^{\circ} \mathrm{C}$ for $2 \mathrm{~h}$. The Fe-35Cr and $\mathrm{Fe}-40 \mathrm{Cr}$ had the lowest weight gain rates, showing excellent high-temperature oxidation resistance because of the $\mathrm{Cr}_{2} \mathrm{O}_{3}$ and $\mathrm{Fe}_{2} \mathrm{O}_{3}$ oxide scales that protected the underlying substrate. The high-temperature oxidation resistance of the $\mathrm{Fe}-35 \mathrm{Cr}$ and $\mathrm{Fe}-40 \mathrm{Cr}$ coatings was close to that of the Ni-Cr-Ti coatings.

A study by Xin et al. [28] compared the oxidation resistance of arc-sprayed FeCrNiNbBSiW with FeCrNiNbBSiMo. FeCrNiNbBSiW exhibited higher temperature oxidation resistance due to the compact coating microstructure with lower porosity and fewer splashed particles. The oxidized products $\mathrm{FeO}(\mathrm{Fe}, \mathrm{Cr})_{2} \mathrm{O}_{3}$ and $(\mathrm{Fe}, \mathrm{Cr})_{2} \mathrm{O}_{3} / \mathrm{Cr}_{2} \mathrm{O}_{3}$, listed in Table 4, formed after the temperature increased from $550{ }^{\circ} \mathrm{C}$ to $650{ }^{\circ} \mathrm{C}$, acted as protection from further oxidation. Figure 7 shows that the oxidation process of the weight gain curves obeys parabolic law. The weight gains increased rapidly at the initial stage of oxidation and slowed gradually before reaching a stable rate. The parabolic law can be expressed by the following Equation (2) [83]:

$$
(\Delta W)^{2}=K t
$$

where $\Delta W$ is the weight gain per unit area $\left(\mathrm{mg} / \mathrm{cm}^{2}\right), K$ is the constant for oxidation rate, and $t$ is the exposure time.

In the study by Luo et al. [84], FeMnCrAl/ $\mathrm{Cr}_{3} \mathrm{C}_{2}$ coatings had a higher temperature oxidation resistance than $\mathrm{FeMnCr} / \mathrm{Cr}_{3} \mathrm{C}_{2}$ coating, 316L stainless steel coating, and AISI 20 steel. The good coating properties were attributed to the formation of compact $\mathrm{Al}$ and $(\mathrm{Fe}, \mathrm{Cr}$ )-rich oxides that protected the coating from further oxidation. The oxide films, however, were unevenly distributed in the coating because of the porosity and the micro-inhomogeneous composition of the arc-sprayed coatings. Zhang et al. [13] compared high-temperature oxidation properties of HVAS FeCrBAlMo with FeCrBSiMo coatings. The coating with $\mathrm{Al}$ had better oxidation resistance than the coating with $\mathrm{Si}$. Al reduced the formation of oxides for other elements and blocked pores in the coating, forming a denser FeCrBAlMo coating structure with higher bonding strength. Alumina and chromium 
oxides also formed on the surface and densified the coating to protect them from further deterioration.

Table 4. Summary of the high-temperature oxidation behavior of arc-sprayed Fe-based coatings.

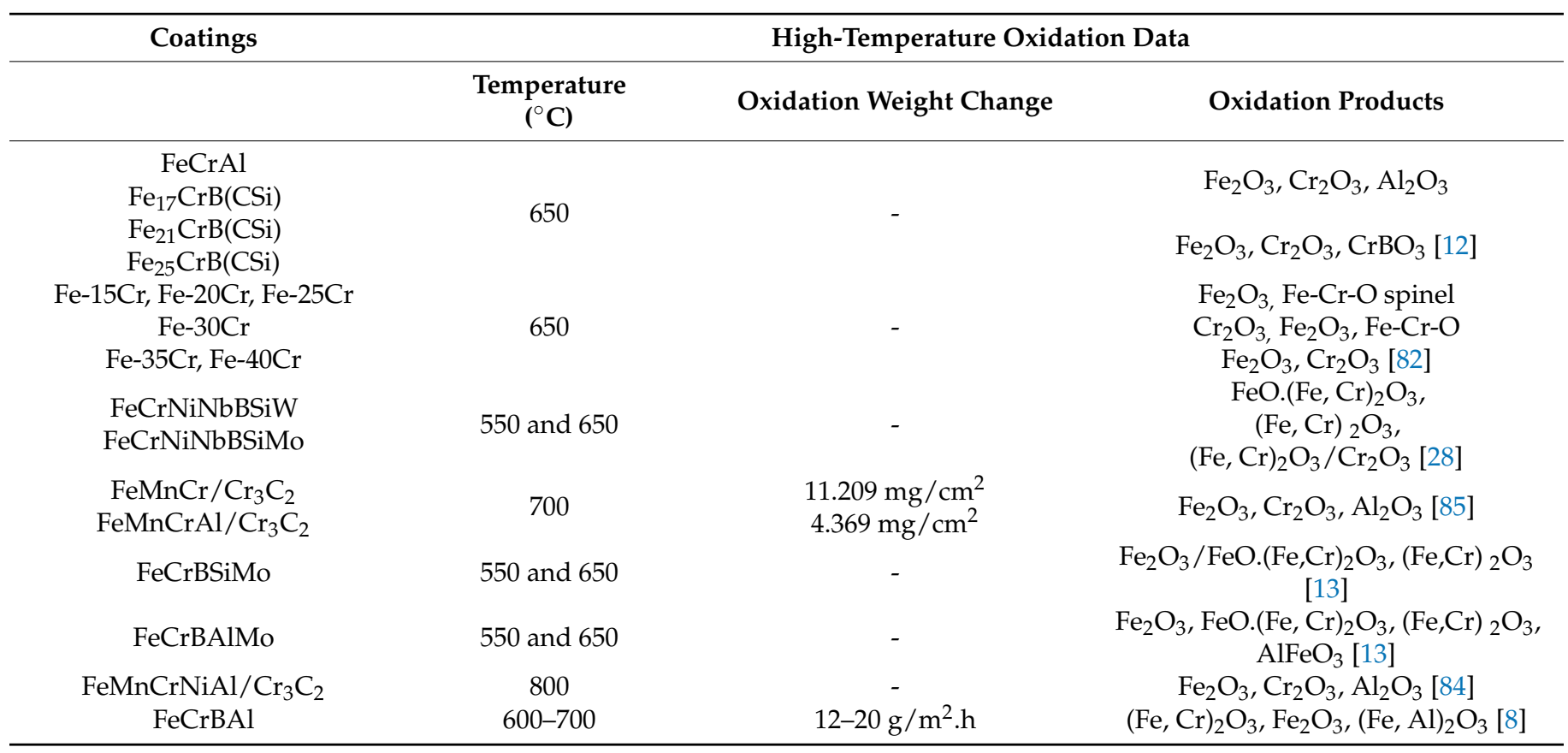
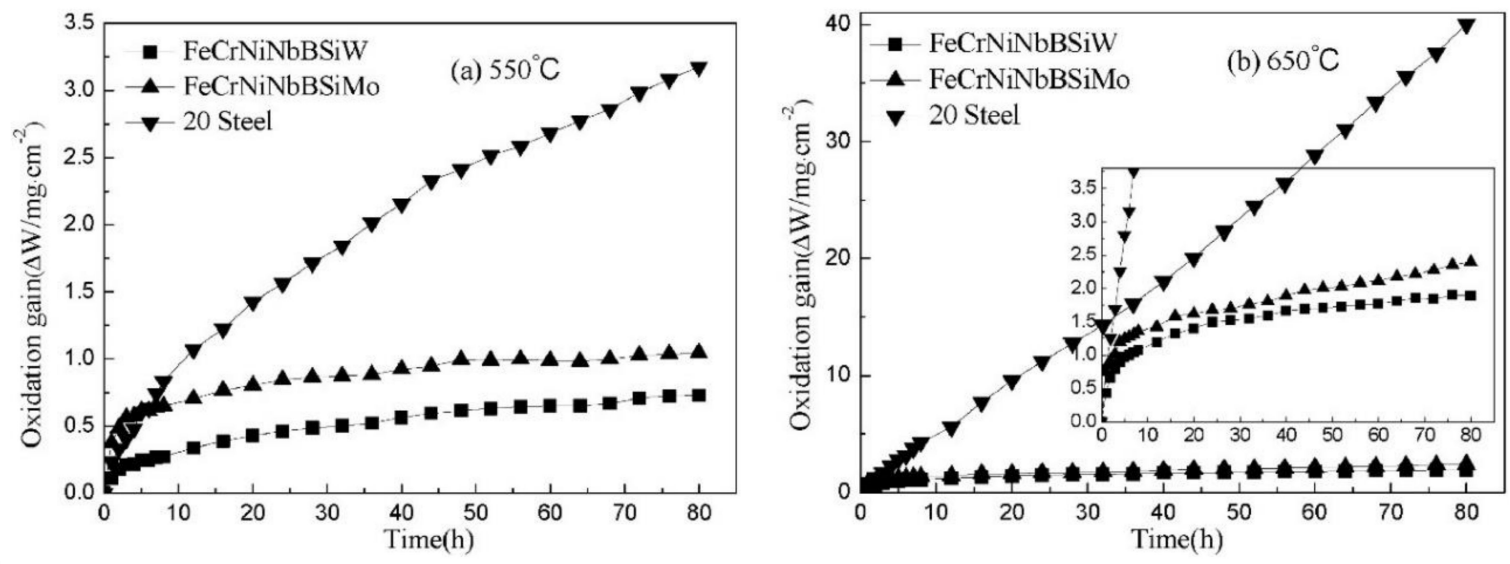

Figure 7. Oxidation kinetics curves of FeCrNiNbBSiW coating, FeCrNiNbBSiMo coating and AISI 20 steel at (a) $550{ }^{\circ} \mathrm{C}$ and (b) $650^{\circ} \mathrm{C}$. Reprinted with permission from ref. [28]. Copyright 2015 Elsevier.

Oxidation tests conducted by Wielage et al. [8] and Vasyl et al. [85] explained the different morphology of oxides formed according to the chemical composition of individual lamellae. Figure 8 shows the oxide films that formed on different lamellae of the arcsprayed coating [8,85]. The needle-shaped $\mathrm{Fe}_{2} \mathrm{O}_{3}$ formed on the lamellae with low $\mathrm{Al}$ and $\mathrm{Cr}$ content, monolithic clusters of chromium oxide or alloyed hematite $(\mathrm{Fe}, \mathrm{Cr})_{2} \mathrm{O}_{3}$ formed on the lamellae with higher $\mathrm{Cr}$ content, while a dense flat oxide film $(\mathrm{Fe}, \mathrm{Al})_{2} \mathrm{O}_{3}$ formed on the Al-rich lamellae. According to [86], the Fe-based coatings also formed distinctive morphologies depending on their chemical composition. At $800{ }^{\circ} \mathrm{C}$, dense oxide films formed and with increase in temperature to $900{ }^{\circ} \mathrm{C}$, the pores and cracks were filled by a netted oxide scale, which effectively protected the substrate during the long-term exposure. 


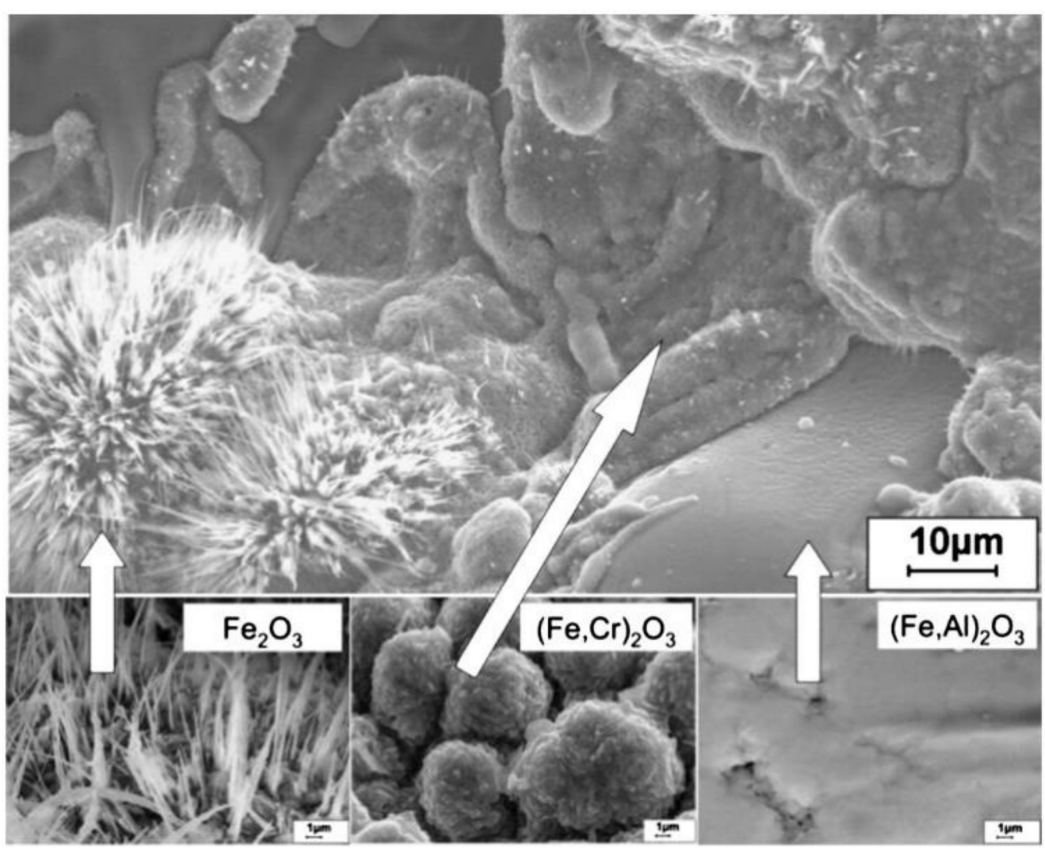

Figure 8. Different morphology of the oxide scales formed on the various lamellae of arc-sprayed coating Cr6B3Al4. Reprinted with permission from ref. [8]. Copyright 2013 Elsevier.

In conclusion, the high-temperature oxidation of the Fe-based coatings depends on the formation of oxide scales that protect the coatings from further oxidation. Suitable alloying elements such as $\mathrm{Cr}$ and $\mathrm{Al}$ should be selected and their compositions optimized to enhance the high-temperature oxidation resistance.

\subsubsection{High-Temperature Erosion (HTE) Behavior}

High-temperature erosion (HTE) has led to the deterioration of turbines, and fluidized bed combustion boilers exposed to particulates flow and fly ash particles. Different factors such as impact angle, impingement velocity, and temperature affect erosion resistance of thermally sprayed coatings. Luo et al. [14] investigated the effects of Al content $(0,8,15$ at. $\%$ ) on the erosion properties of the $\mathrm{FeMnCrAl} / \mathrm{Cr}_{3} \mathrm{C}_{2}$ coating. Sample coatings with $15 \% \mathrm{Al}$ had the best HTE resistance because of the finer microstructure with low oxide inclusions and pores. The coating without $\mathrm{Al}$ had the highest erosion rate under particle impacting. The high amount of oxide fractions weakened the bonding of splats and propagated cracks leading to brittle breaking and lamellar spalling. This study provides a major contribution in the advancement of knowledge on the effects of elemental composition on HTE behavior. Narrow grain size distribution of powders can be applied in arc-spraying cored wires to improve the erosion resistance as used in HVOF thermally sprayed WC-Co-Cr coatings. Narrow powder grain size distribution $(36-45 \mu \mathrm{m})$ coating gave a higher erosion-corrosion resistance than wider grain size distribution $(15-45 \mu \mathrm{m})$ because of the different melting behaviors. Overheating of small grains produced phases with lower erosion resistance, hence poor coating quality, while large grains were insufficiently heated, leading to a more porous coating [87]. Nanoparticle coatings produced have higher hardness and toughness as a result of the low porosity and coating defects, which can significantly affect the erosion resistance properties.

The erosion rate of materials at different impact angles can be expressed by Equation (3):

$$
\mathrm{E}=A \cos ^{2} \beta \sin (n \beta)+B \sin ^{2} \beta
$$

where $\mathcal{E}$ is the erosion rate, $\beta$ is the impingement angle, $n$ is a constant, and $A, B$ are also constants that describe the brittle and plastic behavior, respectively. For brittle material, $A=0$, and typical plastic material, $B=0$, and other material, the plastic materials show 
the main effects at a low impingement angle while the brittle materials display at a high impingement angle. At high impingement angles, brittle materials have low erosion resistance but they have high erosion resistance at low impingement angle, and it is reversed for plastic materials [88,89].

$\mathrm{Xu}$ et al. [10] showed that the impingement angle and the temperature affected the erosion loss of the arc-sprayed $\mathrm{Fe}-\mathrm{Al} / \mathrm{Cr}_{3} \mathrm{C}_{2}$ coatings. The erosion loss of the coatings decreased with increasing temperature and it was higher at $30^{\circ}$ impingement angle than at $90^{\circ}$. During $\mathrm{HTE}$ of $\mathrm{Fe}-\mathrm{Al} / \mathrm{Cr}_{3} \mathrm{C}_{2}$, oxidation films formed, preventing subsequent erosion of particles.

Yong et al. [22] observed the HTE behavior of arc-sprayed FeTi/CrB coating on $20 \mathrm{~g}$ steel substrates under different impact angles and temperatures as shown in Figure 9. The coating had excellent HTE resistance because of its high spalling resistance, high ultimate strength, and toughness. In addition, the $\mathrm{CrB}, \mathrm{FeB}$, and oxide films combined into a solid solution which provided good protection against erosion. The FeTi/CrB coating had an excellent erosion resistance compared with the SH-SAM coating. The erosion mechanisms of different coatings are listed in Table 5.
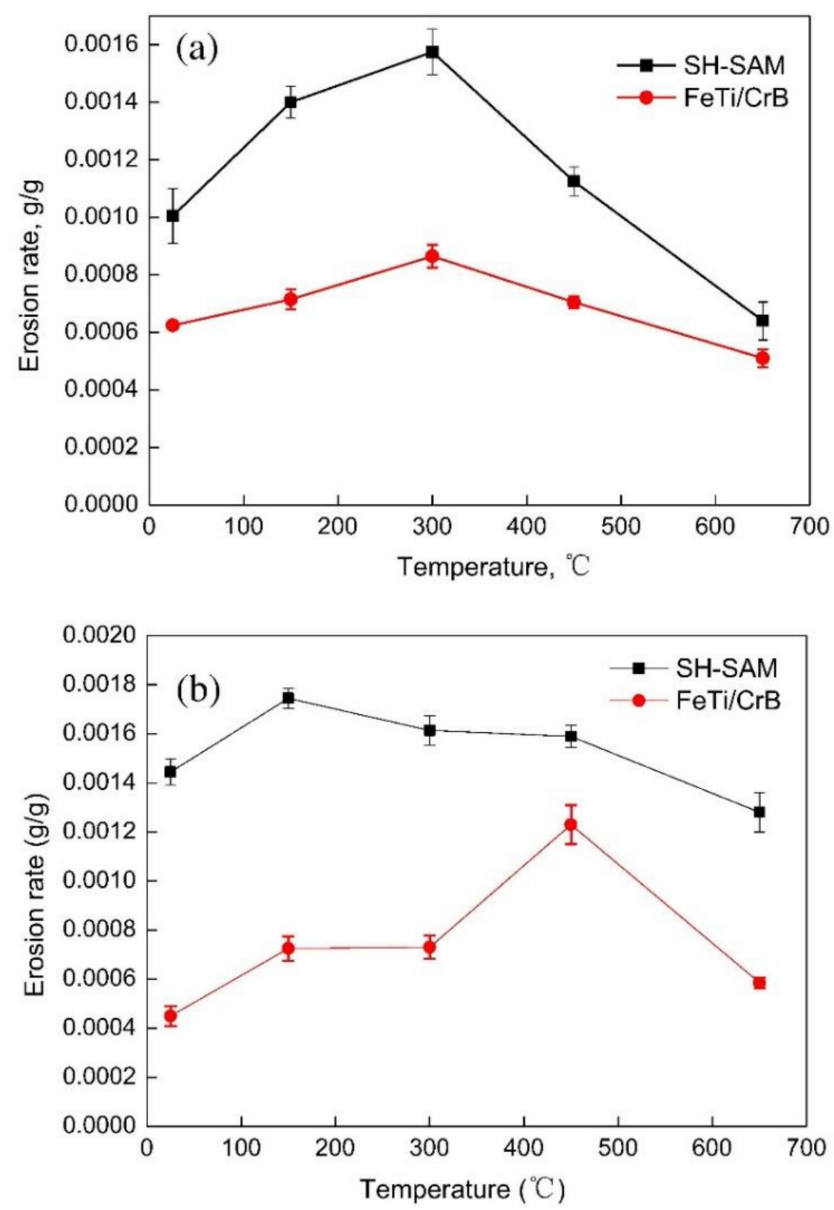

Figure 9. Erosion rates of $\mathrm{FeTi} / \mathrm{CrB}$ and $\mathrm{SH}-\mathrm{SAM}$ coatings at (a) $30^{\circ}$ and (b) $90^{\circ}$ impact angles. Reprinted with permission from ref. [22]. Copyright 2015 Elsevier.

In a comparison study of HVAS Ni-Cr matrix alloy (45PS and SL30) with $\mathrm{FeAl} / \mathrm{Cr}_{3} \mathrm{C}_{2}$ coatings [10], the HTE-wear properties were studied using flying ash particles at different temperatures. The erosion rate of all the coatings decreased with an increase in temperature. The surface of the $\mathrm{FeAl} / \mathrm{Cr}_{3} \mathrm{C}_{2}$ coating formed $\mathrm{Cr}_{2} \mathrm{O}_{3}, \mathrm{FeCr}_{2} \mathrm{O}_{4}$, and $\mathrm{Al}_{2} \mathrm{O}_{3}$ oxides while the $\mathrm{Ni}-\mathrm{Cr}$ alloys formed $\mathrm{NiO}, \mathrm{Cr}_{2} \mathrm{O}_{3}$, and $\mathrm{NiCr}_{2} \mathrm{O}_{4}$ oxides that protected the coatings from further oxidation at $550^{\circ} \mathrm{C}$. Cheng et al. [89] discussed the erosion resistance of arc-sprayed $\mathrm{FeBSiNb}$ amorphous coatings at different impact angles, temperatures, and velocities. 
The erosion resistance of the coating was attributed to the following: as the temperature increased, more nanoscale grains formed, improving the coating microhardness and preventing material removal; thick oxide scales formed and erosion took place on the formed oxide scale; oxidation of the coating and eroded ash particles led to weight gain, which embedded on the coating surface, hence reduction in the erosion rates. The erosion rate of FeBSiNb increased with increasing velocity and followed the empirical power law of erosion given by Equation (4):

$$
\varepsilon=K v^{n}
$$

where $\mathrm{E}$ is the erosion rate, $K$ is a constant, $v$ is the velocity, and $n$ has values between 2.2 and 3.0 [90].

Table 5. Summary of the high-temperature erosion behavior of arc-sprayed Fe-based coatings.

\begin{tabular}{|c|c|c|c|}
\hline \multirow[t]{2}{*}{ Coatings } & \multicolumn{3}{|c|}{ High-Temperature Erosion } \\
\hline & Temperature ${ }^{\circ} \mathrm{C}$ & Impact Angle & Erosion Behavior \\
\hline Alpha 1800 & $\begin{array}{l}\text { Room temperature (RT), } \\
300,400,500,600\end{array}$ & $30^{\circ}$ and $90^{\circ}$ & $\begin{array}{l}\text { Erosion damage was by extrusion-forging } \\
\text { mechanism. Shallow craters formed by } \\
\text { particle impact and subsequent impact } \\
\text { forged platelets into the surface [91] }\end{array}$ \\
\hline $\mathrm{FeBSiNb}$ & $300,450,600$ & $30^{\circ}$ and $90^{\circ}$ & $\begin{array}{c}\text { Lower erosion rate at impact angle of } 30^{\circ} \\
\text { and erosion rate decreased with increasing } \\
\text { temperature. Mass loss attributed to splat } \\
\text { flaking. Main failure mechanism was } \\
\text { brittle fracture [89] }\end{array}$ \\
\hline $\mathrm{FeAl} / \mathrm{Cr}_{3} \mathrm{C}_{2}$ & $550,650,800$ & $90^{\circ}$ & $\begin{array}{c}\text { Erosion rates decreased with increasing } \\
\text { temperature. } \mathrm{Fe}_{2} \mathrm{O}_{3}, \mathrm{Al}_{2} \mathrm{O}_{3} \text {, and } \mathrm{Cr}_{2} \mathrm{O}_{3} \\
\text { oxides formed protection coating from } \\
\text { further oxidation [10] }\end{array}$ \\
\hline $\begin{array}{l}\text { FeCrBSiMnNbY } \\
\text { FeBSiNbCr }\end{array}$ & $25,300,450,650$ & $30^{\circ}$ and $90^{\circ}$ & $\begin{array}{l}\text { Erosion rates decreased with increasing } \\
\text { temperature. FeBSiNbCr had better } \\
\text { corrosion resistance than FeCrBSiMnNbY. } \\
\text { Erosion mechanism is the brittle breaking } \\
\text { and fracture mechanism [92] }\end{array}$ \\
\hline $\mathrm{FeTi} / \mathrm{CrB}$ & $20,150,300,450,650$ & $30^{\circ}, 60^{\circ}$, and $90^{\circ}$ & $\begin{array}{c}\text { Erosion rate increased with increasing } \\
\text { impact angle. Abrasive cutting and plough } \\
\text { wearing were the main erosion } \\
\text { mechanisms [22] }\end{array}$ \\
\hline $\begin{array}{c}\mathrm{FeMnCr} / \mathrm{Cr}_{3} \mathrm{C}_{2} \\
\text { FeMnCr8Al } / \mathrm{Cr}_{3} \mathrm{C}_{2} \\
\text { FeMnCr} 15 \mathrm{Al} / \mathrm{Cr}_{3} \mathrm{C}_{2}\end{array}$ & 900 & $30^{\circ}, 45^{\circ}, 60^{\circ}$, and $90^{\circ}$ & $\begin{array}{l}\text { Erosion mechanism was through brittle } \\
\text { breaking, cutting, and fatigue spalling [14] }\end{array}$ \\
\hline
\end{tabular}

Future research could focus on the effects of compositions of different alloying elements on high-temperature erosion resistance of arc-sprayed coatings.

\subsubsection{High-Temperature Corrosion Behavior}

Hot corrosion generally refers to the accelerated oxidation of metals and alloys at intermediate temperatures $\left(600-850^{\circ} \mathrm{C}\right)$ associated with mixed molten salts (e.g., sulphates deposited by alkali metals). Few studies on the high-temperature corrosion properties have been reported and further research on the effect of elemental compositions could be undertaken. Shukla et al. [93] fabricated arc-sprayed FeCrBSiMn coating with superior high-temperature corrosion resistance exposed to a molten salt environment $\left(\mathrm{Na}_{2} \mathrm{SO}_{4}-\right.$ $\left.82 \% \mathrm{Fe}_{2}\left(\mathrm{SO}_{4}\right)_{3}\right)$ at $900{ }^{\circ} \mathrm{C}$ under cyclic conditions for 50 cycles. They noted that the oxides of $\mathrm{Fe}$ and $\mathrm{Cr}$ enhanced the corrosion resistance of the coatings. $\mathrm{Xu}$ et al. [10] prepared HVAS $\mathrm{Fe}-\mathrm{Al} / \mathrm{Cr}_{3} \mathrm{C}_{2}$ coatings on 20-grade steel. The coatings had a lower corrosion rate than the substrate. The Fe-Al matrix composites and $\mathrm{Cr}_{2} \mathrm{C}_{3}$ had good corrosion properties and the oxides formed protected the coatings. The corrosion rate increased with temperature 
but later slowed down with increased time. $\mathrm{Cr}_{2} \mathrm{O}_{3}$ facilitated the formation of $\mathrm{Al}_{2} \mathrm{O}_{3}$ that further protected the coating. Guo et al. [94] studied the hot corrosion resistance of FeCrBC in a mixed solution of $\mathrm{Na}_{2} \mathrm{SO}_{4}+\mathrm{K}_{2} \mathrm{SO}_{4}(7: 3)$ at $700{ }^{\circ} \mathrm{C}$ for $156 \mathrm{~h}$. Thin films of $\mathrm{Cr}_{2} \mathrm{O}_{3}$ formed on the coating and separated the alloy from the mixed salt solution, thus providing better resistance to hot corrosion. In a comparison study by Li et al. [11], the arc-sprayed $\mathrm{FeCrSiB}$ coatings provided better hot corrosion resistance than $\mathrm{FeCr}$, approaching that of NiCrTi coating. The weight gain for the hot corrosion has been calculated as follows:

$$
\Delta W_{i}=\left[\frac{W_{i+2}-W_{i}}{A}\right]-\left[\frac{W_{i+1}-W_{i}}{A}\right] \times 0.6
$$

where, $W_{i}$ is the mass of the sample before the ${ }_{i}{ }^{t h}$ corrosion, $W_{i+1}$ is the mass after the first salt coating, $W_{i+2}$ is the mass after the ${ }_{i}{ }^{\text {th }}$ corrosion, $A$ is the total surface area of the sample, and 0.6 is the coefficient for deducting the salt film crystal water.

The microstructure and chemical composition of the coating material is equally as important and interlayer pores can act as channels for molten salts degrading the underlying coating. Therefore, the coating should be sprayed carefully to avoid penetration of molten salts into the coating [95]. Table 6 summarizes the hot corrosion behavior of the Fe-based coatings.

In the study of hot corrosion behavior, the coating porosity is the key to reducing the corrosion rate. Dense coatings have a better hot corrosion resistance than porous coatings. Corrosion attack on the grain boundaries occurs because of the slipping of the corrosive medium into the substrate [96]. Compared with their crystalline counterparts, most Fe-based amorphous coatings show better corrosion resistance because they lack grain boundaries, cracks, and interfacial defects. Hot corrosion behavior could be used to further explore the corrosion mechanisms of arc-sprayed Fe-based amorphous coatings at elevated temperature.

Table 6. Summary of the hot corrosion behavior of arc-sprayed Fe-based coatings.

\begin{tabular}{cccc}
\hline Coatings & Corrosive Environment & Temperature $\left.{ }^{\circ} \mathbf{C}\right)$ & Hot Corrosion Behavior \\
\hline $\mathrm{FeCrSiB}$ & $\mathrm{Na}_{2} \mathrm{SO}_{4}-25 \% \mathrm{~K}_{2} \mathrm{SO}_{4}$ & 650 & $\begin{array}{c}\text { Formation of } \mathrm{Cr}_{2} \mathrm{O}_{3} \text { and } \mathrm{SiO}_{2} \mathrm{mixed} \\
\text { scale with low diffusion coefficients } \\
\text { preventing further penetration of } \\
\text { solution [11]. }\end{array}$ \\
\hline $\mathrm{FeCrBSiMn}$ & $\mathrm{Na}_{2} \mathrm{SO}_{4}-82 \% \mathrm{Fe}_{2}\left(\mathrm{SO}_{4}\right)_{3}$ & 900 & $\begin{array}{c}\text { Fe and } \mathrm{Cr} \text { enhanced the corrosion } \\
\text { resistance of the coatings [93]. }\end{array}$ \\
\hline $\mathrm{Fe}-\mathrm{Al} / \mathrm{Cr}_{3} \mathrm{C}_{2}$ & $\mathrm{Na}_{2} \mathrm{SO}_{4}+\mathrm{K}_{2} \mathrm{SO}_{4}(7: 3)$ & $450,650,800$ & $\begin{array}{c}\text { The formation of } \mathrm{Cr}_{2} \mathrm{O}_{3} \text { oxides speeded } \\
\text { the formation of } \mathrm{Al} \mathrm{O}_{3}, \text { which } \\
\text { protected the coatings [10]. }\end{array}$ \\
\hline $\mathrm{FeCrBC}$ & $\mathrm{Na}_{2} \mathrm{SO}_{4}+\mathrm{K}_{2} \mathrm{SO}_{4}(7: 3)$ & 700 & $\begin{array}{c}\text { Compact and dense Cr} \mathrm{O}_{3} \text { acted as } \\
\text { diffusion barriers for the solution [94]. }\end{array}$ \\
\hline $\mathrm{FeNiCr} / \mathrm{Cr} \mathrm{C}_{2}$ & $\mathrm{Na}_{2} \mathrm{SO}_{4}+\mathrm{K}_{2} \mathrm{SO}_{4}(7: 3)$ & 700 & $\begin{array}{c}\text { Oxidation, sulfidation, and internal } \\
\text { sulfidation were the main hot corrosion } \\
\text { mechanisms [97] }\end{array}$ \\
\hline
\end{tabular}

\subsubsection{High-Temperature Wear Behavior}

Several studies have shown the relation between the coating integrity and the coating's high-temperature wear performance. Stress concentration occurs at the defects such as cracks on the coating, which propagate coating failure during the wear process [98]. The coating hardness, cohesive strength of the coating, and bond strength of the coating with substrate influence the high-temperature wear properties.

A study on FeAl intermetallic coatings [99] showed a low wear rate at elevated temperatures of up to $650{ }^{\circ} \mathrm{C}$. The oxide films protected the worn surfaces by minimizing the wear 
rate. Additionally, the high strength and coating hardness resisted further propagation of crack failure and fracture of the coating at high temperatures. FeAl intermetallic coatings displayed high-temperature oxidation resistance by adding $\mathrm{Cr}_{3} \mathrm{C}_{2}$, which improves the abrasion resistance. The coatings had a high wear resistance at room temperature, which decreased with increasing temperature. High hardness and formation of $\mathrm{Al}_{2} \mathrm{O}_{3}$ and $\mathrm{Cr}_{2} \mathrm{O}_{3}$ oxides maintained a higher wear resistance than that of the 20-grade steel. At high temperatures, peeling was the primary wear behavior for the HVAS Fe-Al/ $\mathrm{Cr}_{3} \mathrm{C}_{2}$ coatings [10]. Zhu et al. [100] studied the friction and wear behavior of $\mathrm{Fe}-\mathrm{Al} / \mathrm{WC}$ intermetallic coating at temperatures of $650{ }^{\circ} \mathrm{C}$. During the wear process, a protective oxide layer formed, providing solid lubrication and reducing direct contact with the friction counterpart material. The high-temperature strength and high-temperature hardness prevented the propagation of cracks and fracture of particles in the process of sliding wear. Wielage et al. [8] showed that the amount of $\mathrm{Al}$ content $(2,6,14 \mathrm{wt}$. \%) on the hot gas abrasive wear affected the wear loss and microhardness of the arc-sprayed coatings. At temperatures of up to $600{ }^{\circ} \mathrm{C}$, arc-sprayed $\mathrm{FeCrBAl}$ coatings with 2 wt. \% and $6 \mathrm{wt}$. \% Al content had poorer wear resistance than steel substrate but coatings with $14 \mathrm{wt}$. \% $\mathrm{Al}$ content had better wear resistance (Figure 10). Figure 10a,b show the influence of $\mathrm{Al}$ content on the weight loss and hardness during the high-temperature abrasive test. The coating with high $\mathrm{Al}$ content had improved wear resistance due to the increased coating heterogeneity and the reduced tensile stresses as a result of the oxidation of microcracks and oxidation of the lamellae. Therefore, the hot gas abrasive wear resistance of the coatings depends on the chemical composition of the arc-sprayed coating, residual stresses in the coating, and the chemical homogeneity of element distribution. These factors determine the oxidation intensity in the coating exposed to high temperatures. Precipitation phases formed at high temperatures strengthen the coating to improve the wear resistance. Table 7 summarizes the wear mechanisms of Fe-based coatings at high temperatures.
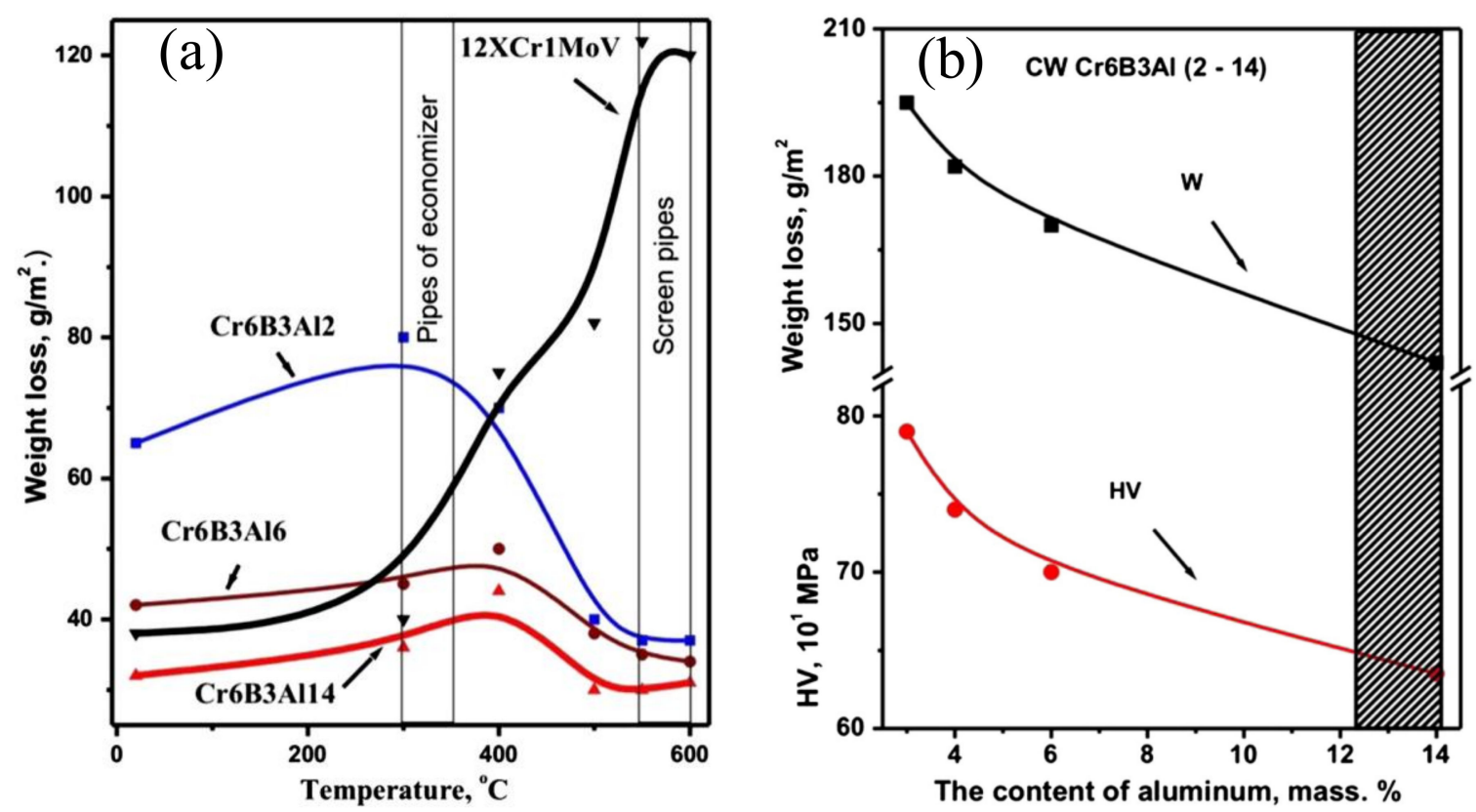

Figure 10. (a) Hot gas abrasive resistance of arc-sprayed coatings with different Al content. (b) Effect of Al content in the cored wires on the weight loss and microhardness during high-temperature abrasive wear test. Reprinted with permission from ref. [8]. Copyright 2013 Elsevier. 
Table 7. Summary of the high-temperature wear behavior of arc-sprayed Fe-based coatings.

\begin{tabular}{|c|c|c|}
\hline Coatings & Temperature & High-Temperature Wear Behavior \\
\hline $\mathrm{FeAl}$ & Up to $650{ }^{\circ} \mathrm{C}$ & $\begin{array}{l}\text { Coefficient of friction decreased with temperature increase and protective film formed } \\
\text { during the sliding process. Delamination was the main wear mechanism. High } \\
\text { strength and hardness } \mathrm{Fe}_{3} \mathrm{Al} \text { and FeAl intermetallics prevented crack propagation and } \\
\text { fracture of splats [99]. }\end{array}$ \\
\hline $\mathrm{FeAl} / \mathrm{Cr}_{3} \mathrm{C}_{2}$ & Up to $600^{\circ} \mathrm{C}$ & $\begin{array}{l}\text { Main wear mechanism was peeling wear. The } \mathrm{Cr}_{2} \mathrm{O}_{3} \text { facilitated the formation of } \\
\mathrm{Al}_{2} \mathrm{O}_{3} \text { to reduce the wear loss, High hardness and the good amalgamation between } \\
\text { the } \mathrm{Cr}_{3} \mathrm{C}_{2} \text { and FeAl intermetallics improved the coating ductility [10]. }\end{array}$ \\
\hline $\mathrm{FeAl} / \mathrm{WC}$ & Up to $650{ }^{\circ} \mathrm{C}$ & $\begin{array}{c}\text { Main wear mechanism was delamination. Coefficient of friction decreased due to } \\
\text { oxide films that acted as a solid lubricant during sliding wear [100]. }\end{array}$ \\
\hline $\mathrm{FeCrBAl}$ & $600^{\circ} \mathrm{C}$ & $\begin{array}{l}\text { Increased } \mathrm{Al} \text { content improved the wear resistance. Lower tensile stresses formed as } \\
\text { the coating heterogeneity increased with an increase in } \mathrm{Al} \text { content. Reduction of } \\
\text { tensile stresses was due to the oxidation of microcracks and coating lamellae [8]. }\end{array}$ \\
\hline
\end{tabular}

In conclusion, the phase composition of the coatings and the oxides formation controlled the high-temperature wear, oxidation, corrosion, and erosion resistance. The oxide scales generated stresses that determined the spalling and cracking of the coatings. Adding alloying elements such as $\mathrm{Al}$ and $\mathrm{Cr}$ is vital to form oxides that reduce the wear and corrosion rate at high temperatures. The coating defects undermine the coating protection at high temperatures, hence the need to minimize them through process optimization. The high-temperature wear resistance has mostly been characterized by the weight gain and weight reduction of the coatings. The degradation of coatings in corrosive medium at high temperature involves the combination of wear process and the electrochemical corrosion process. The corrosion-wear behavior of arc-sprayed Fe-based coatings should be investigated at high temperatures to further understand the tribological properties.

\section{Conclusions and Future Scope Recommendations}

Arc-spraying is a reliable and effective technique used in the production of Fe-based coatings. Arc-sprayed Fe-based coatings are recommended for application in boilers, steam pipes, and components operating at high temperatures due to the high resistance offered with respect to oxidation, corrosion, wear, and erosion. Fe-based coatings have potential to be used as alternatives to some of the Ni-based coatings because of their relatively lower costs and availability of raw materials. Some Ni-based coatings produce oxidation products such as $\mathrm{NiO}$ and $\mathrm{NiCl}_{2}$, which may be harmful to human health [82]. The protective mechanisms of Fe-based coatings were discussed and the following conclusions and recommendations are made:

1. The density, size, and structure of feedstock powders influence the phase composition of the deposited coatings in HVOF and APS thermal spraying methods. Cored wires in arc-spraying can explore the use of different-sized powders as filling materials to optimize the coating properties. Coating powders of arc-sprayed cored wires can apply nanoscale particles that result in densely packed nanostructured coatings [57]. Arc-sprayed $\mathrm{FePSiNb}$ coatings exhibited a nanoscale structure with a grain size range from 12 to $50 \mathrm{~nm}$ with good wear resistance properties [63]. More work will need to be done to determine the production and study of properties of arc-sprayed nanostructured coatings.

2. The spraying parameters play an important role in determining the microstructural properties of the coatings. Optimizing methods such as response surface methodology (RSM) analyzes the interaction between spray parameters and their influence on the coating properties. The effects of process parameters on the amorphization of the arcsprayed coatings could be studied to maximize the amorphous content of Fe-based amorphous coatings.

3. The arc-sprayed Fe-based coatings have better hardness and wear resistance properties than conventional alloys due to the dense microstructure, the dispersion strength- 
ening of the amorphous/nanocrystalline phases, and reinforcement ceramic particles. The elastic properties also determine the wear resistance of the Fe-based coatings.

4. To increase the corrosion resistance, the coating defects (oxides, pores, and cracks) in the Fe-based coatings should be minimized by optimizing spray parameters to prevent the deterioration of coating properties in corrosive media.

5. The high-temperature properties of the Fe-based coating are mainly affected by the microstructure and the elemental composition. The reinforcement ceramic particles added to the Fe-based alloys improve the tribological and high-temperature coating performance while the amorphous phase content is characterized by fewer dislocations, microcracks, and grain boundaries enhancing the properties of the Fe-based amorphous coatings. Future research should focus on understanding the combined corrosion-wear behavior of arc-sprayed Fe-based coatings at elevated temperatures.

6. Adding appropriate alloying elements such as $\mathrm{Al}$ and $\mathrm{Cr}$ to Fe-based coatings improves high-temperature protection by forming oxide scales that prevent further oxidation of the underlying substrate. Future research should investigate the influence of different elements on high-temperature properties of Fe-based coatings.

Author Contributions: Conceptualization, J.N.N. and M.K.; methodology, J.N.N.; software, B.V.G. and S.M.N.; validation, M.K. and J.L.; formal analysis, J.N.N.; investigation, J.N.N. and S.M.N.; resources, J.L.; data curation, J.N.N.; writing—original draft preparation, J.N.N.; writing-review and editing, J.N.N., S.M.N. and B.V.G.; visualization, J.N.N.; supervision, M.K. and J.L.; project administration, M.K.; funding acquisition, M.K. All authors have read and agreed to the published version of the manuscript.

Funding: This research was funded by the Jiangsu Province Modern Agricultural Machinery Equipment and Technology Demonstration and Promotion Project, grant number (NJ2019-22) and Jiangsu Province Key Research and Development (Modern Agriculture), grant number (BE2020311).

Conflicts of Interest: The authors declare no conflict of interest.

\section{References}

1. Fukumoto, M. The current status of thermal spraying in Asia. J. Therm. Spray Technol. 2008, 17, 5-13. [CrossRef]

2. Davis, J.R. Handbook of Thermal Spray technology; ASM International: Materials Park, OH, USA, 2004.

3. Zhang, W.; Guo, Y.-M.; Chen, Y.-X. Applications and future development of thermal spraying technologies for remanufacturing engineering. China Surf. Eng. 2011, 24, 1-10.

4. Szymański, K.; Hernas, A.; Moskal, G.; Myalska, H. Thermally sprayed coatings resistant to erosion and corrosion for power plant boilers-A review. Surf. Coat. Technol. 2015, 268, 153-164. [CrossRef]

5. Steffens, H.-D.; Babiak, Z.; Wewel, M. Recent developments in arc spraying. IEEE Trans Plasma Sci. 1990, 18, 974-979. [CrossRef]

6. Chi, X.; Song, C.; Bao, J.; Gao, Z.; Ren, X.; Ma, B. Research progress on fabrication of composite metal coatings by arc spraying. Therm. Spray Technol. 2019, 11, 72-76.

7. Yadaw, R.C.; Singh, S.K.; Chattopadhyaya, S.; Kumar, S.; Singh, R. Tribological behavior of thin film coating-a review. Int. J. Eng. Technol. 2018, 7, 1656-1663. [CrossRef]

8. Wielage, B.; Pokhmurska, H.; Student, M.; Gvozdeckii, V.; Stupnyckyj, T.; Pokhmurskii, V. Iron-based coatings arc-sprayed with cored wires for applications at elevated temperatures. Surf. Coat. Technol. 2013, 220, 27-35. [CrossRef]

9. Degnan, C.; Shipway, P.J.W. A comparison of the reciprocating sliding wear behaviour of steel based metal matrix composites processed from self-propagating high-temperature synthesised Fe-TiC and Fe-TiB 2 masteralloys. Wear 2002, 252, 832-841. [CrossRef]

10. Xu, W.-P.; Xu, B.-S.; Zhang, W.; Wu, Y.-X. High temperature behaviors of high velocity arc sprayed $\mathrm{Fe}-\mathrm{Al} / \mathrm{Cr}_{3} \mathrm{C}_{2} \mathrm{composite}$ coatings. Int. J. Miner. Metall. Mater. 2005, 12, 340-346.

11. Li, R.; Zhou, Z.; He, D.; Wang, Y.; Wu, X.; Song, X. Microstructure and high temperature corrosion behavior of wire-arc sprayed FeCrSiB coating. J. Therm. Spray Technol. 2015, 24, 857-864. [CrossRef]

12. Li, R.; He, D.Y.; Zhou, Z.; Wang, Z.J.; Song, X.Y. Wear and high temperature oxidation behaviour of wire arc sprayed iron based coatings. Surf. Eng. 2014, 30, 784-790. [CrossRef]

13. Zhang, X.; Wang, Z.; Lin, J. High temperature oxidation behavior of arc-sprayed FeCrBAlMo coating. J. Adv. Oxid. Technol. 2016, 19, 105-112. [CrossRef]

14. Luo, L.-M.; Liu, S.-G.; Jia, Y.; Juan, L.; Jian, L. Effect of Al content on high temperature erosion properties of arc-sprayed FeMnCrAl $/ \mathrm{Cr}_{3} \mathrm{C}_{2}$ coatings. Trans. Nonferr. Met. Soc. China. 2010, 20, 201-206. [CrossRef]

15. Koiprasert, H.; Ch, S.; Sheppard, P. FeAl and FeCrAl as alternative coatings for NiAl. Chiang Mai J. Sci. 2013, 40, 839-848. 
16. Zhang, S.; Du, S.; Zhang, Y. Research progress of Fe-based amorphous alloy coating prepared by thermal spraying. Hot Work Technol. 2010, 39, 89-91.

17. Guo, W.; Wu, Y.; Zhang, J.; Hong, S.; Li, G.; Ying, G.; Guo, J.; Qin, Y. Fabrication and characterization of thermal-sprayed Fe-based amorphous/nanocrystalline composite coatings: An overview. J. Therm. Spray Technol. 2014, 23, 1157-1180. [CrossRef]

18. Cheng, J.B.; Liang, X.B.; Xu, B.S. Devitrification of arc-sprayed FeBSiNb amorphous coatings: Effects on wear resistance and mechanical behavior. Surf. Coat. Technol. 2013, 235, 720-726. [CrossRef]

19. Huang, L.; Yu, S.; Deng, Y.; Dai, M.; Xu, H. Research progress and application of arc spraying cored wires. Mater. Rev. 2011, 25, 63-65.

20. Lotfi, B.; Shipway, P.; McCartney, D.; Edris, H. Abrasive wear behaviour of $\mathrm{Ni}(\mathrm{Cr})-\mathrm{TiB}_{2}$ coatings deposited by $\mathrm{HVOF}$ spraying of SHS-derived cermet powders. Wear 2003, 254, 340-349. [CrossRef]

21. Arizmendi-Morquecho, A.; Campa-Castilla, A.; Leyva-Porras, C.; Aguilar Martinez, J.A.; Vargas Gutiérrez, G.; Moreno Bello, K.J.; López López, L. Microstructural characterization and wear properties of Fe-based amorphous-crystalline coating deposited by twin wire arc spraying. Adv. Mater. Sci. Eng. 2014, 2014, 836739. [CrossRef]

22. Wang, Y.; Sun, C.; Sun, J.; Zhao, W.; Dong, L.; Li, L.; Meng, F. Erosion behavior of arc sprayed FeTi/CrB MMC coating at elevated temperature. Surf. Coat. Technol. 2015, 262, 141-147. [CrossRef]

23. Yao, H.; Zhou, Z.; Wang, Y.; He, D.; Bobzin, K.; Zhao, L.; Öte, M.; Königstein, T. Microstructure and properties of FeCrB alloy coatings prepared by wire-arc spraying. J. Therm. Spray Technol. 2017, 26, 483-491. [CrossRef]

24. He, D. Study on arc-sprayed cored wires and wear properties of coatings. Ph.D Thesis, Beijing University of Technology, Beijing, China, 2004.

25. Cheng, J.; Wang, Z.; Xu, B. Wear and corrosion behaviors of FeCrBSiNbW amorphous/nanocrystalline coating prepared by arc spraying process. J. Therm. Spray Technol. 2012, 21, 1025-1031. [CrossRef]

26. Lin, J.; Wang, Z.; Lin, P.; Cheng, J.; Zhang, J.; Zhang, X. Microstructure and corrosion resistance of Fe-based coatings prepared by twin wires arc spraying process. J. Therm. Spray Technol. 2014, 23, 333-339. [CrossRef]

27. Lin, J.; Wang, Z.; Lin, P.; Cheng, J.; Zhang, X.; Hong, S. Microstructure and cavitation erosion behavior of FeNiCrBSiNbW coating prepared by twin wires arc spraying process. Surf. Coat. Technol. 2014, 240, 432-436. [CrossRef]

28. Zhang, X.; Wang, Z.; Lin, J.; Zhou, Z. A study on high temperature oxidation behavior of high-velocity arc sprayed Fe-based coatings. Surf. Coat. Technol. 2015, 283, 255-261. [CrossRef]

29. Xu, B.; Zhu, Z.; Ma, S.; Zhang, W.; Liu, W. Sliding wear behavior of Fe-Al and Fe-Al/WC coatings prepared by high velocity arc spraying. Wear 2004, 257, 1089-1095. [CrossRef]

30. Fu, B.-Y.; He, D.-Y.; Zhao, L.-D.; Li, X.-Y. Microstructure characterisation and wear properties of arc sprayed NiB containing amorphous coatings. Surf. Eng. 2009, 25, 326-332. [CrossRef]

31. Fu, B.-Y.; He, D.-Y.; Zhao, L.-D.; Jiang, J.-M.; Li, X.-Y. Microstructure and properties of arc sprayed coatings containing Fe based amorphous phase and nanocrystallites. Surf. Eng. 2009, 25, 333-337. [CrossRef]

32. Tian, H.; Wang, C.; Tang, Z.; Wei, S.; Xu, B.; Que, M. Effect of high velocity arc spraying parameters on properties of FeNiCrAl coating. J. Aeroun. Mater. 2016, 36, 40-47.

33. Tian, H.; Wei, S.; Chen, Y.; Tong, H.; Liu, Y.; Xu, B.S. Adhesive strength and abrasive property of Fe based composite coating deposited by high velocity arc spraying. Mater Res Innov. 2014, 18, S2-363-S2-367. [CrossRef]

34. Tian, H.; Wei, S.; Chen, Y.; Tong, H.; Lui, Y.; Xu, B. Properties of FeCrAl/Ni95Al coating by high velocity arc spraying. Heat Treat. Metals 2013, 38, 92-96.

35. Daram, P.; Munroe, P.; Banjongprasert, C. Microstructural evolution and nanoindentation of NiCrMoAl alloy coating deposited by arc spraying. Surf. Coat. Technol. 2020, 391, 125565. [CrossRef]

36. Kant, S.; Kumar, M.; Chawla, V.; Singh, S. Study of high temperature oxidation behavior of wire arc sprayed coatings. Mater. Today Proc. 2020, 21, 1741-1748. [CrossRef]

37. Kumar, S.; Kumar, M.; Handa, A. Comparative study of high temperature oxidation behavior and mechanical properties of wire arc sprayed NiCr and NiAl coatings. Eng. Fail. Anal. 2019, 106, 104173. [CrossRef]

38. Cheng, J.; Wu, Y.; Chen, L.; Hong, S.; Qiao, L.; Wei, Z. Hot corrosion behavior and mechanism of high-velocity arc-sprayed Ni-Cr alloy coatings. J. Therm. Spray Technol. 2019, 28, 1263-1274. [CrossRef]

39. Talib, R.; Saad, S.; Toff, M.; Hashim, H. Thermal spray coating technology: A review. Solid State Sci Technol. 2003, 11, 109-117.

40. Takalapally, S.; Kumar, S.; Pusuluri, S.H.; Palle, M. A critical review on surface coatings for engineering materials. Int. J. Mech. Eng. Technol. 2016, 7, 80-85.

41. Liu, G.; Rożniatowski, K.; Kurzydłowski, K. Quantitative characteristics of FeCrAl films deposited by arc and high-velocity arc spraying. Mater. Charact. 2001, 46, 99-104. [CrossRef]

42. Zhan, J.; Li, Z.; Lu, J.; Wu, Y.; Zhao, L.; Yu, N. Technics and performance analysis of Monel alloy coating prepared by high velocity arc spraying. Mater. Res. Innov. 2013, 17, 112-114. [CrossRef]

43. Boronenkov, V.; Korobov, Y. Fundamentals of Arc Spraying; Springer International Publishing: Geneva, Switzerland, 2016; (Physical and Chemical Regularities).

44. Liu, S.-G.; Wu, J.-M.; Zhang, S.-C.; Rong, S.-J.; Li, Z.-Z. High temperature erosion properties of arc-sprayed coatings using various cored wires containing Ti-Al intermetallics. Wear 2007, 262, 555-561. [CrossRef] 
45. Tillmann, W.; Hagen, L.; Kokalj, D. Spray characteristics and tribo-mechanical properties of high-velocity arc-sprayed WC-W $\mathrm{W}_{2} \mathrm{C}$ iron-based coatings. J. Therm. Spray Technol. 2017, 26, 1685-1700. [CrossRef]

46. Zeng, Z.-s.; Sakoda, N.; Tajiri, T. Corrosion behavior of wire-arc-sprayed stainless steel coating on mild steel. J. Therm. Spray Technol. 2006, 15, 431-437. [CrossRef]

47. Jandin, G.; Liao, H.; Feng, Z.; Coddet, C. Correlations between operating conditions, microstructure and mechanical properties of twin wire arc sprayed steel coatings. Mater. Sci. Eng. A-Struct. Mater. Prop. Microstruct. Process. 2003, 349, 298-305. [CrossRef]

48. Horner, A.L.; Hall, A.C.; McCloskey, J.F. The effect of process parameters on twin wire arc spray pattern shape. Coatings 2015, 5, 115-123. [CrossRef]

49. Johnston, A.L.; Hall, A.C.; McCloskey, J.F. Effect of process inputs on coating properties in the twin-wire arc zinc process. J. Therm. Spray Technol. 2013, 22, 856-863. [CrossRef]

50. Li, Z.-R.; Li, D.-Y.; Zhang, N.-N.; Huang, H.; Wang, X. Wear mechanism of iron-based alloy coating by arc spraying. J. Iron Steel Res. Int. 2016, 23, 834-841. [CrossRef]

51. Fu, B.-Y.; He, D.-Y.; Zhao, L.-D. Effect of heat treatment on the microstructure and mechanical properties of Fe-based amorphous coatings. J. Alloys Compd. 2009, 480, 422-427. [CrossRef]

52. Newbery, A.; Grant, P. Oxidation during electric arc spray forming of steel. J. Mater. Process. Technol. 2006, 178, 259-269. [CrossRef]

53. Ndiithi, N.J.; Kang, M.; Zhu, J.; Lin, J.; Nyambura, S.M.; Liu, Y.; Huang, F. Microstructural and corrosion behavior of high velocity arc sprayed $\mathrm{FeCrAl} / \mathrm{Al}$ composite coating on Q235 steel substrate. Coatings 2019, 9, 542. [CrossRef]

54. Brezinová, J.; Landová, M.; Guzanová, A.; Dulebová, L'.; Draganovská, D. Microstructure, wear behavior and corrosion resistance of WC-FeCrAl and WC-WB-Co coatings. Metals 2018, 8, 399. [CrossRef]

55. Ding, P.; Liu, X.-J.; Liu, J.-J.; Li, J.-B.; Li, H.-Q.; Zhao, H.-Y.; Duan, J.-Y.; Jiao, Y.-Z. Study on the properties of FeCrNi/CBN composite coating with high velocity arc spraying. Arab J. Chem. 2018, 11, 935-941. [CrossRef]

56. Newbery, A.; Grant, P.; Neiser, R. The velocity and temperature of steel droplets during electric arc spraying. Surf. Coat. Technol. 2005, 195, 91-101. [CrossRef]

57. Basak, A.; Zein Eddine, W.; Celis, J.-P.; Matteazzi, P. Characterisation and tribological investigation on thermally processed nanostructured Fe-based and Cu-based cermet materials. J. Nanosci. Nanotechnol. 2010, 10, 1179-1184. [CrossRef]

58. Cheng, J.-B.; Liang, X.-B.; Xu, B.-S.; Wu, Y.-X. Formation and properties of Fe-based amorphous/nanocrystalline alloy coating prepared by wire arc spraying process. J. Non-Cryst. Solids. 2009, 355, 1673-1678. [CrossRef]

59. Cheng, J.; Liang, X.; Xu, B.; Wu, Y. Characterization of mechanical properties of FeCrBSiMnNbY metallic glass coatings. J. Mater. Sci. 2009, 44, 3356-3363. [CrossRef]

60. Leyland, A.; Matthews, A. Design criteria for wear-resistant nanostructured and glassy-metal coatings. Surf. Coat. Technol. 2004, 177, 317-324. [CrossRef]

61. YH, K.; Hiraga, K.; Inoue, A.; Masumoto, T. Crystallization and high mechanical strength of Al-based amorphous alloys. Mater. Trans. JIM. 1994, 35, 293-302.

62. Cheng, J.; Liang, X.; Wang, Z.; Xu, B. Microstructure and mechanical properties of FeBSiNb metallic glass coatings by twin wire arc spraying. J. Therm. Spray Technol. 2013, 22, 471-477. [CrossRef]

63. Cheng, J.; Liu, Q.; Sun, B.; Liang, X.; Zhang, B. Structural and tribological characteristics of nanoscale FePSiBNb coatings. J. Therm. Spray Technol. 2017, 26, 530-538. [CrossRef]

64. He, D.-Y.; Fu, B.-Y.; Jiang, J.-M.; Li, X.-Y. Microstructure and wear performance of arc sprayed Fe-FeB-WC coatings. J. Therm. Spray. Technol. 2008, 17, 757-761. [CrossRef]

65. Yan, Y.; Wei, X.; Jiang, H.; Ying, C.; Shen, J. Research on microstructure and friction and wear properties of Fe-based amorphous alloy coatings prepared by arc spraying. Hot Work Technol. 2018, 47, 117-121.

66. Wu, D.; Fan, Z.S.; Yang, Y. Formation and properties of Fe-based amorphous/nanocrystalline alloy coating prepared by wire arc spraying process. In Materials Science Forum; Trans Tech Publications: Zürich, Switzerland, 2019; pp. $499-505$.

67. Tian, H.; Wei, S.; Chen, Y.; Tong, H.; Liu, Y.; Xu, B. Wear behavior of high velocity arc spraying FeNiCrAlBRE/Ni95Al composite coatings. Physics Procedia 2013, 50, 282-287. [CrossRef]

68. Zhang, B.; Cheng, J.; Liang, X. Effects of $\mathrm{Cr}$ and Mo additions on formation and mechanical properties of Arc-sprayed FeBSiNbbased glassy coatings. J. Non-Cryst. Solids. 2018, 499, 245-251. [CrossRef]

69. Cheng, J.; Liang, X.; Xu, B.; Wu, Y. Microstructure and wear behavior of FeBSiNbCr metallic glass coatings. J. Mater. Sci. Technol. 2009, 25, 687-690.

70. Tian, H.; Wei, S.; Chen, Y.; Tong, H.; Liu, Y.; Xu, B. Microstructure and wear resistance of an arc-sprayed Fe-based coating after surface remelting treatment. Strength Mater. 2014, 46, 229-234. [CrossRef]

71. Peng, Y.; Zhang, C.; Zhou, H.; Liu, L. On the bonding strength in thermally sprayed Fe-based amorphous coatings. Surf. Coat. Technol. 2013, 218, 17-22. [CrossRef]

72. Niu, P.-F.; Tian, B.-L. Wear compensation model based on the theory of archard and definite integral method. Math. Probl. Eng. 2018, 2018. [CrossRef]

73. Kumar, D.; Murtaza, Q.; Singh, R.C. Sliding wear behavior of aluminum alloy coating prepared by two-wire electric arc spray process. Int. J. Adv. Manuf. Technol. 2016, 85, 237-252. [CrossRef]

74. Cheng, J.; Liang, X.; Wang, Z.; Xu, B. Dry sliding friction and wear properties of metallic glass coating and martensite stainless coating. Tribol. Int. 2013, 60, 140-146. [CrossRef] 
75. Leyland, A.; Matthews, A. On the significance of the H/E ratio in wear control: A nanocomposite coating approach to optimised tribological behaviour. Wear 2000, 246, 1-11. [CrossRef]

76. Chen, X.; Du, Y.; Chung, Y.-W. Commentary on using $\mathrm{H} / \mathrm{E}$ and $\mathrm{H}^{3} / \mathrm{E}^{2}$ as proxies for fracture toughness of hard coatings. Thin Solid Film. 2019, 688, 137265. [CrossRef]

77. Ahmed, N.; Bakare, M.; McCartney, D.; Voisey, K. The effects of microstructural features on the performance gap in corrosion resistance between bulk and HVOF sprayed Inconel 625. Surf. Coat. Technol. 2010, 204, 2294-2301. [CrossRef]

78. Belkhaouda, M.; Bazzi, L.; Benlhachemi, A.; Salghi, R.; Hammouti, B.; Kertit, S. Effect of the heat treatment on the corrosion behaviour of amorphous Fe-Cr-P-C-Si alloy in $0.5 \mathrm{M} \mathrm{H}_{2} \mathrm{SO}_{4}$. Appl. Surf. Sci. 2006, 252, 7921-7925. [CrossRef]

79. Lin, J.; Wang, Z.; Lin, P.; Cheng, J.; Zhang, X.; Hong, S. Effect of crystallisation on electrochemical properties of arc sprayed FeNiCrBSiNbW coatings. Surf Eng. 2014, 30, 683-687. [CrossRef]

80. Cheng, J.; Liang, X.; Xu, B. Effects of crystallization on the corrosion resistance of arc-sprayed FeBSiNb coatings. J. Therm. Spray Technol. 2014, 23, 373-379. [CrossRef]

81. Yoo, Y.H.; Lee, S.H.; Kim, J.G.; Kim, J.S.; Lee, C. Effect of heat treatment on the corrosion resistance of Ni-based and Cu-based amorphous alloy coatings. J. Alloy Compd. 2008, 461, 304-311. [CrossRef]

82. Li, R.; Zhou, Z.; He, D.; Zhao, L.; Song, X. Microstructure and high-temperature oxidation behavior of wire-arc sprayed Fe-based coatings. Surf. Coat. Technol. 2014, 251, 186-190. [CrossRef]

83. Zhuang, X.; Tan, Y.; You, X.; Li, P.; Zhao, L.; Cui, C.; Zhang, H.; Cui, H. High temperature oxidation behavior and mechanism of a new Ni-Co-based superalloy. Vacuum 2021, 189, 110219. [CrossRef]

84. Li, Y.; Liang, T.; Ao, R.; Zhao, H.; Chen, X.; Zeng, J. Oxidation resistance of iron-based coatings by supersonic arc spraying at high temperature. Surf. Coat. Technol. 2018, 347, 99-112. [CrossRef]

85. Luo, L.-M.; Luo, J.; Liu, S.-G.; Liu, Y.-l.; Li, J. Microstructure and high temperature oxidation resistance of FeMnCrAl/Cr3C2 coatings deposited by high velocity arc spraying. Trans. Mater. Heat Treat. 2010, 31, 139-142. (In Chinese)

86. Pokhmurskii, V.; Student, M.; Gvozdeckii, V.; Stypnutskyy, T.; Student, O.; Wielage, B.; Pokhmurska, H. Arc-sprayed iron-based coatings for erosion-corrosion protection of boiler tubes at elevated temperatures. J. Therm. Spray Technol. 2013, 22, 808-819. [CrossRef]

87. Berget, J.; Rogne, T.; Bardal, E. Erosion-corrosion properties of different WC-Co-Cr coatings deposited by the HVOF processinfluence of metallic matrix composition and spray powder size distribution. Surf. Coat. Technol. 2007, 201, 7619-7625. [CrossRef]

88. Guo, J.; Bin-shi, X.; Hai-dou, W.; Liang, Y.; Qing-fen, L.; Shi-cheng, W.; Xiufang, C. Erosion behavior of EEDS cermet coatings. Appl. Surf. Sci. 2008, 254, 5470-5474. [CrossRef]

89. Cheng, J.; Liang, X.; Chen, Y.; Wang, Z.; Xu, B. High-temperature erosion resistance of FeBSiNb amorphous coatings deposited by arc spraying for boiler applications. J. Therm. Spray Technol. 2013, 22, 820-827. [CrossRef]

90. Shewmon, P.; Sundararajan, G. The erosion of metals. Ann. Rev. of Mater. Sci. 1983, 13, 301-318. [CrossRef]

91. Venugopal, K.; Agrawal, M. Evaluation of arc sprayed coatings for erosion protection of tubes in atmospheric fluidised bed combustion (AFBC) boilers. Wear 2008, 264, 139-145. [CrossRef]

92. Liang, X.B.; Cheng, J.B.; Bai, J.Y.; Xu, B.S. Erosion properties of Fe based amorphous/nanocrystalline coatings prepared by wire arc spraying process. Surf. Eng. 2010, 26, 209-215. [CrossRef]

93. Shukla, V.; Rana, N.; Jayaganthan, R.; Tewari, V. Degradation Studies of Wire arc Sprayed FeCrBSiMn alloy Coating in Molten Salt Environment. Procedia Eng. 2014, 75, 113-117. [CrossRef]

94. Wenmin, G.; Yuping, W.; Gaiye, L.; Qian, W.; Zhihua, H.; Sheng, H. Hot corrosion behavior of a high velocity arc-sprayed Fe-Cr-BC coating. Rare Met. Mat. Eng. 2012, 41, 456-459.

95. Seong, B.G.; Hwang, S.Y.; Kim, K.Y. High-temperature corrosion of recuperators used in steel mills. Surf. Coat. Technol. 2000, 126, 256-265. [CrossRef]

96. Sidhu, B.S.; Prakash, S. Performance of NiCrAlY, Ni-Cr, Stellite- 6 and Ni3Al coatings in $\mathrm{Na}_{2} \mathrm{SO}_{4}-60 \%$ V2O5 environment at 900 C under cyclic conditions. Surf. Coat. Technol. 2006, 201, 1643-1654. [CrossRef]

97. Guo, W.-M.; Wu, Y.-P.; Li, G.-Y.; Hong, S.; He, Z.-H. Hot corrosion of FeNiCr $/ \mathrm{Cr}_{3} \mathrm{C}_{2}$ and NiCrTi arc spray coatings on mild steel. Trans. Mater. Heat Treat. 2011, 32, 128-134.

98. Li, X.; Dong, T.; Li, G.; Zhou, X.; Zheng, X. Research status and development trend of high temperature wear resistance of thermal spraying coatings. Hot Work. Technol. 2018, 47, 32-36.

99. Xu, B.-S.; Zhu, Z.-X.; Liu, Y.; Ma, S.-N.; Zhang, W. Fe-Al intermetallics coating produced by high velocity arc spraying. Chin. J. Nonferr. Met. 2004, 14, 154-158.

100. Zhu, Z.-X.; Xu, B.-S.; Ma, S.-N.; Du, Z.-Y.; Liu, W.-M. Tribological properties of Fe-Al/WC composite coating prepared by high velocity arc spraying. Tribology-Beijing 2003, 23, 174-178. (In Chinese) 